\title{
The atmospheric chemistry of sulphuryl fluoride, $\mathrm{SO}_{2} \mathrm{~F}_{2}$
}

\section{T. J. Dillon, A. Horowitz, and J. N. Crowley}

Max Planck Institute for Chemistry, Mainz, Germany

Received: 4 October 2007 - Published in Atmos. Chem. Phys. Discuss.: 25 October 2007

Revised: 24 January 2008 - Accepted: 13 February 2008 - Published: 13 March 2008

Abstract. The atmospheric chemistry of sulphuryl fluoride, $\mathrm{SO}_{2} \mathrm{~F}_{2}$, was investigated in a series of laboratory studies. A competitive rate method, using pulsed laser photolysis (PLP) to generate $\mathrm{O}\left({ }^{1} \mathrm{D}\right)$ coupled to detection of $\mathrm{OH}$ by laser induced fluorescence (LIF), was used to determine the overall rate coefficient for the reaction $\mathrm{O}\left({ }^{1} \mathrm{D}\right)+\mathrm{SO}_{2} \mathrm{~F}_{2} \rightarrow$ products (R1) of $k_{1}$ $(220-300 \mathrm{~K})=(1.3 \pm 0.2) \times 10^{-10} \mathrm{~cm}^{3}$ molecule $^{-1} \mathrm{~s}^{-1}$.

Monitoring the $\mathrm{O}\left({ }^{3} \mathrm{P}\right)$ product $(\mathrm{R} 1 \mathrm{a})$ enabled the contribution $(\alpha)$ of the physical quenching process (in which $\mathrm{SO}_{2} \mathrm{~F}_{2}$ is not consumed) to be determined as $\alpha$ (225$296 \mathrm{~K})=(0.55 \pm 0.04)$. Separate, relative rate measurements at $298 \mathrm{~K}$ provided a rate coefficient for reactive loss of $\mathrm{O}\left({ }^{1} \mathrm{D}\right), \quad k_{1 \mathrm{~b}}, \quad$ of $\quad(5.8 \pm 0.8) \times 10^{-11} \mathrm{~cm}^{3}$ molecule $^{-1} \mathrm{~s}^{-1}$ in good agreement with the value calculated from $(1-\alpha) \times k_{1}=(5.9 \pm 1.0) \times 10^{-11} \mathrm{~cm}^{3}$ molecule $\mathrm{s}^{-1} \mathrm{~s}^{-1}$. Upper limits for the rate coefficients for reaction of $\mathrm{SO}_{2} \mathrm{~F}_{2}$ with $\mathrm{OH}$ (R2, using PLP-LIF), and with $\mathrm{O}_{3}$ (R3, static reactor) were determined as $k_{2}(294 \mathrm{~K})<1 \times 10^{-15} \mathrm{~cm}^{3}$ molecule ${ }^{-1} \mathrm{~s}^{-1}$ and $k_{3}(294 \mathrm{~K})<1 \times 10^{-23} \mathrm{~cm}^{3}$ molecule ${ }^{-1} \mathrm{~s}^{-1}$. In experiments using the wetted-wall flow tube technique, no loss of $\mathrm{SO}_{2} \mathrm{~F}_{2}$ onto aqueous surfaces was observed, allowing an upper limit for the uptake coefficient of $\gamma(\mathrm{pH} 2-12)<1 \times 10^{-7}$ to be determined. These results indicate that $\mathrm{SO}_{2} \mathrm{~F}_{2}$ has no significant loss processes in the troposphere, and a very long stratospheric lifetime. Integrated band intensities for $\mathrm{SO}_{2} \mathrm{~F}_{2}$ infrared absorption features between 6 and $19 \mu \mathrm{m}$ were obtained, and indicate a significant global warming potential for this molecule. In the course of this work, ambient temperature rate coefficients for the reactions $\mathrm{O}\left({ }^{1} \mathrm{D}\right)$ with several important atmospheric species were determined. The results (in units of $10^{-10} \mathrm{~cm}^{3}$ molecule ${ }^{-1} \mathrm{~s}^{-1}$ ), $k_{\left(\mathrm{O}^{1} \mathrm{D}+\mathrm{N}_{2}\right)}=(0.33 \pm 0.06) ; \quad k_{\left(\mathrm{O}^{1} \mathrm{D}+\mathrm{N}_{2} \mathrm{O}\right)}=(1.47 \pm 0.2) \quad$ and $k_{\left(\mathrm{O}^{1} \mathrm{D}+\mathrm{H}_{2} \mathrm{O}\right)}=(1.94 \pm 0.5)$ were in good agreement with other recent determinations.

Correspondence to: T. J. Dillon (dillon@mpch-mainz.mpg.de)

\section{Introduction}

Sulphuryl fluoride, $\mathrm{SO}_{2} \mathrm{~F}_{2}, \quad$ (Vikane $^{\mathrm{TM}}$, Zythor $^{\mathrm{TM}}$, ProFume ${ }^{\mathrm{TM}}$ ) is a widely used fumigant of timber, buildings, construction materials and vehicles. 30 years have passed since $\mathrm{SO}_{2} \mathrm{~F}_{2}$ was first mentioned in the context of a potential influence on stratospheric sulphur chemistry (Crutzen, 1976) and in this period the use of $\mathrm{SO}_{2} \mathrm{~F}_{2}$ has been extended to the food processing and agriculture industries as a replacement for $\mathrm{CH}_{3} \mathrm{Br}$ (banned under the Montreal protocol). The main consumer of $\mathrm{SO}_{2} \mathrm{~F}_{2}$ is the US state of California where annual usage has exceeded $10^{6} \mathrm{~kg}$ since 1999 (Kollman, 2006). Indeed, $\mathrm{SO}_{2} \mathrm{~F}_{2}$ has recently been detected for the first time in ambient air samples (Mühle et al., 2006). These first ambient measurements of $\mathrm{SO}_{2} \mathrm{~F}_{2}$ provided the motivation for us to undertake a series of laboratory investigations into the kinetics of reactions of $\mathrm{SO}_{2} \mathrm{~F}_{2}$ with atmospheric oxidants and surfaces, for which no data existed. The UV absorption spectrum of $\mathrm{SO}_{2} \mathrm{~F}_{2}$ has been measured (Pradayrol et al., 1996) and the results demonstrate that photolysis is an insignificant loss process in the troposphere. Cady and Misra (1974) have measured hydrolysis rates for $\mathrm{SO}_{2} \mathrm{~F}_{2}$ in aqueous solutions. Their results indicate that hydrolysis is slow in acidic or neutral conditions, but may be an efficient atmospheric loss process in basic conditions (i.e. at the ocean surface). There are no published data regarding potential gas-phase atmospheric loss processes for $\mathrm{SO}_{2} \mathrm{~F}_{2}$, or heterogeneous uptake to surfaces. Nonetheless, an upperlimit to the atmospheric lifetime of $\mathrm{SO}_{2} \mathrm{~F}_{2}$ of $\tau \leq 4.5$ years has been suggested (European Union Report, 2005). In the present study, a variety of laboratory techniques were used to measure rate coefficients, $k$, for the gas-phase (R1-R3) of $\mathrm{SO}_{2} \mathrm{~F}_{2}$ with the atmospheric oxidants $\mathrm{O}\left({ }^{1} \mathrm{D}\right), \mathrm{OH}$, and $\mathrm{O}_{3}$, and the rate of heterogeneous uptake of $\mathrm{SO}_{2} \mathrm{~F}_{2}$ to aqueous surfaces (R4):

$$
\begin{aligned}
\mathrm{O}\left({ }^{1} \mathrm{D}\right)+\mathrm{SO}_{2} \mathrm{~F}_{2} & \rightarrow \mathrm{O}\left({ }^{3} \mathrm{P}\right)+\mathrm{SO}_{2} \mathrm{~F}_{2} \\
& \rightarrow \text { (other products) }
\end{aligned}
$$

Published by Copernicus Publications on behalf of the European Geosciences Union. 
$\mathrm{OH}+\mathrm{SO}_{2} \mathrm{~F}_{2} \rightarrow$ (products)

$\mathrm{O}_{3}+\mathrm{SO}_{2} \mathrm{~F}_{2} \rightarrow$ (products)

$\mathrm{SO}_{2} \mathrm{~F}_{2}+\mathrm{H}_{2} \mathrm{O}(\mathrm{aq}) \rightarrow$ (products)

Note that $\mathrm{SO}_{2} \mathrm{~F}_{2}$ is consumed in all processes except for (R1a). The kinetic data obtained in this work is used to estimate the lifetime of $\mathrm{SO}_{2} \mathrm{~F}_{2}$ in the atmosphere and thus its impact on various aspects of atmospheric science.

\section{Experimental}

The experiments were conducted using a variety of laboratory techniques and equipment. The gas phase experiments utilised both real time techniques (pulsed laser photolysis coupled to laser induced fluorescence (PLP-LIF) or resonance fluorescence (PLP-RF)), a relative rate technique with Fourier transform infrared spectroscopy (RR-FTIR) and a simple static mixing approach with UV analysis. A potential heterogeneous loss process (uptake of $\mathrm{SO}_{2} \mathrm{~F}_{2}$ to aqueous surfaces) was investigated using the wetted-wall flow tube technique (WWFT). These are described in turn below.

\subsection{PLP-LIF/RF}

The PLP-LIF and PLP-RF techniques have been used in this laboratory to study reactions of $\mathrm{O}\left({ }^{1} \mathrm{D}\right)$ (Dillon et al., 2007), $\mathrm{O}\left({ }^{3} \mathrm{P}\right)$ (Teruel et al., 2004), IO (Dillon et al., 2006)) and OH (Wollenhaupt et al., 2000; Karunanandan et al., 2007). The experimental set-up has been described in detail previously (see for example Wollenhaupt et al. (2000), which includes a schematic diagram of the apparatus) and is outlined only briefly here. Experiments were conducted in a $500 \mathrm{~cm}^{3}$ quartz reactor, the temperature of which was regulated by circulating a cryogenic fluid through the outer jacket, and monitored with a J-Type thermocouple. The reactor pressure was monitored with a capacitance manometer. Gas flow rates of $300-2500 \mathrm{~cm}^{3}$ (STP) $\mathrm{min}^{-1}$ ensured that a fresh gas sample was available for photolysis at each laser pulse. Chemistry was initiated by an excimer laser (Lambda Physik) operating at $248 \mathrm{~nm}(\mathrm{KrF})$.

Fluorescence from $\mathrm{OH}$ was detected by a photomultiplier tube (PMT) shielded by $309 \mathrm{~nm}$ (interference) and BG 26 (glass cut-off) filters. Excitation of the $A^{2} \Sigma(v=1) \leftarrow \mathrm{X}^{2} \Pi$ $(v=0), Q_{11}$ transition of $\mathrm{OH}$ at $281.997 \mathrm{~nm}$ was achieved using the frequency doubled emission from a Nd-YAG (Quantel) pumped dye laser (Lambda Physik/rhodamine 6G).

Resonance emission used to $\operatorname{detect} \mathrm{O}\left({ }^{3} \mathrm{P}\right)$ at $\sim 131 \mathrm{~nm}$ was generated by microwave discharge $(80 \mathrm{~W})$ through $99.999 \%$ $\mathrm{He}$ at $\sim 3$ Torr, and passed through a set of baffles and a $\mathrm{CaF}_{2}$ window (to remove radiation from excited $\mathrm{H}$ or $\mathrm{N}$ atoms) before entering the cell perpendicular to both the pulsed emission from the excimer photolysis laser and the VUV photomultiplier detection axis. Fluorescence was gathered by a $f=1.4$ telescopic arrangement and focussed onto the active area of the VUV photomultiplier. Time dependent $\mathrm{O}\left({ }^{3} \mathrm{P}\right)$ signals were amplified, digitised and counted by a multichannel scaler usually operating at a resolution of $5 \mu$ s per channel, and averaging 1000 decay profiles.

In the experiments designed to study $(\mathrm{R} 1), \mathrm{O}\left({ }^{1} \mathrm{D}\right)$ was generated by the $248 \mathrm{~nm}$ photolysis of $\mathrm{O}_{3}(\mathrm{R} 5)$. $\mathrm{O}\left({ }^{1} \mathrm{D}\right)$ was not detected directly, but converted to $\mathrm{OH}$ by reaction with a straight-chain alkane $n-\mathrm{C}_{5} \mathrm{H}_{12}$ (R6) or $n-\mathrm{C}_{6} \mathrm{H}_{14}$ (R7), and in a few experiments $\mathrm{H}_{2} \mathrm{O}(\mathrm{R} 8)$. All $\mathrm{H}$ atom donors were present at $\approx 2 \times 10^{13}$ molecule $\mathrm{cm}^{-3}$.

$\mathrm{O}_{3}+h v(248 \mathrm{~nm}) \rightarrow \mathrm{O}\left({ }^{1} \mathrm{D}\right)+\mathrm{O}_{2}$

$\mathrm{O}\left({ }^{1} \mathrm{D}\right)+n-\mathrm{C}_{5} \mathrm{H}_{12} \rightarrow \mathrm{OH}+$ (other products)

$\mathrm{O}\left({ }^{1} \mathrm{D}\right)+n-\mathrm{C}_{6} \mathrm{H}_{14} \rightarrow \mathrm{OH}+$ (other products)

$\mathrm{O}\left({ }^{1} \mathrm{D}\right)+\mathrm{H}_{2} \mathrm{O} \rightarrow 2 \mathrm{OH}$

The $248 \mathrm{~nm}$ photolysis of $\mathrm{H}_{2} \mathrm{O}_{2}$ (R9) was used to generate $\mathrm{OH}$ in the experiments to determine $k_{2}(294 \mathrm{~K})$.

$\mathrm{H}_{2} \mathrm{O}_{2}+h v(248 \mathrm{~nm}) \rightarrow 2 \mathrm{OH}$

Typically, laser fluences of $12 \mathrm{~mJ} \mathrm{~cm}^{-2}$ per pulse were used to generate $\left[\mathrm{O}\left({ }^{1} \mathrm{D}\right)\right]$ or $[\mathrm{OH}]$ of $\approx 2 \times 10^{11}$ molecule $\mathrm{cm}^{-3}$. Concentrations of the radical precursors $\mathrm{O}_{3}\left(<2 \times 10^{12}\right.$ molecule $\left.\mathrm{cm}^{-3}\right)$ and $\mathrm{H}_{2} \mathrm{O}_{2}$ $\left(\sim 3 \times 10^{13}\right.$ molecule $\left.\mathrm{cm}^{-3}\right)$ were determined optically by monitoring the attenuation of light (185 or $254 \mathrm{~nm})$ from a Hg lamp transmitting a $43.8 \mathrm{~cm}$ absorption cell situated downstream of the reactor. Due to the small absorption cross-sections of $\mathrm{SO}_{2} \mathrm{~F}_{2}$ at suitable wavelengths, optical measurements of $\left[\mathrm{SO}_{2} \mathrm{~F}_{2}\right]$ were not possible. Concentrations of the excess reagents $\mathrm{SO}_{2} \mathrm{~F}_{2}, n-\mathrm{C}_{5} \mathrm{H}_{12}, n-\mathrm{C}_{6} \mathrm{H}_{14}, \mathrm{~N}_{2}, \mathrm{~N}_{2} \mathrm{O}$, and $\mathrm{H}_{2} \mathrm{O}$ were therefore determined by manometric methods to an estimated (minimum) accuracy of $\pm 15 \%$ ( $\pm 30 \%$ for $\mathrm{H}_{2} \mathrm{O}$ ) based upon uncertainties in (calibrated) mass flow rates, $T$ and $P$.

\subsection{RR-FTIR}

Relative rate experiments were carried out in a cylindrical quartz reactor cell of volume 451 , fitted with internal multipass optics to give an effective optical path-length of $28 \mathrm{~m}$ (Raber and Moortgat, 2000). Photolysis was provided by 9 UV lamps (Philips, TUV $40 \mathrm{~W}$ ) evenly distributed around the outside of the reactor and flushed with compressed air to prevent warming of the ambient air directly in contact with the reactor surface. Static mixtures of $\mathrm{O}_{3}, \mathrm{SO}_{2} \mathrm{~F}_{2}\left(\mathrm{or} \mathrm{SF}_{6}\right)$ and $\mathrm{N}_{2} \mathrm{O}$ were prepared in the cell and approximate concentrations determined manometrically. The relative rate experiments were conducted at a total pressure of $\approx 200$ Torr $(\mathrm{He})$ and the gas mixture was left to stand for $>20 \mathrm{~min}$ to ensure mixing and thermalization. FTIR spectra $\left(450-2000 \mathrm{~cm}^{-1}\right.$, $0.5 \mathrm{~cm}^{-1}$ resolution, typically 256 co-added scans) were 
recorded prior to, and at regular intervals after UV irradiation using a Bomem DA-008 spectrometer with a MCT detector. The variation of the concentration of $\mathrm{N}_{2} \mathrm{O}$ and $\mathrm{SO}_{2} \mathrm{~F}_{2}$ with irradiation time was determined by repeating the alternating irradiation and spectra acquisition steps, and by preparing new mixtures which were then photolysed for different exposure times. The exposure times were always shorter than $300 \mathrm{~s}$ and no change in the cell temperature was observed over this period. The relative change in the concentration of the two reactants was derived by fitting the observed spectra to the initial reference using absorption features between 578 and $603 \mathrm{~cm}^{-1}$ for $\mathrm{N}_{2} \mathrm{O}$ and between 1438 and $1566 \mathrm{~cm}^{-1}$ for $\mathrm{SO}_{2} \mathrm{~F}_{2}$.

The same spectrometer was used to measure quantitative IR spectra of $\mathrm{SO}_{2} \mathrm{~F}_{2}$, but using a $50 \mathrm{~cm}^{3}$ volume, single pass glass optical absorption cell (optical path-length $15 \mathrm{~cm}$ ) equipped with Si optical windows.

\subsection{WWFT}

The uptake of $\mathrm{SO}_{2} \mathrm{~F}_{2}$ to aqueous surfaces was investigated using the wetted-wall flow tube technique. The apparatus used has been described in previous publications (Fickert et al., 1998, 1999) and only salient features are given here. $\mathrm{SO}_{2} \mathrm{~F}_{2}$ was introduced via a movable injector into a laminar flow tube reactor (internal radius $=7.75 \mathrm{~mm}$ ) operated at a pressure of about $250-290$ Torr and at $T=277 \mathrm{~K}$. The bulk gas was He, flowed at $\approx 300 \mathrm{sccm}$, resulting in a Reynolds number of 2.5 , and a linear velocity of $\approx 4 \mathrm{~cm} \mathrm{~s}^{-1}$. Flow rates were monitored by freshly calibrated mass flow controllers and are expected to be accurate to a few percent. The pressure was monitored with a 1000 Torr capacitance manometer. The inner wall of the flow tube was coated with a slowly flowing aqueous film which was prepared from bulk solutions with $\mathrm{pH}$ adjusted to $2,4.5$ or 12 . The thickness and speed of the liquid film were calculated as described previously (Fickert et al., 1998) to be $\approx 100 \mu \mathrm{m}$ and $3-4 \mathrm{~cm} \mathrm{~s}^{-1}$, respectively.

The contact time between $\mathrm{SO}_{2} \mathrm{~F}_{2}$ and the aqueous film was varied by translating the moveable injector using a computer controlled linear drive to accurately maintain axial alignment between the injector and the aqueous film. Using the relatively slow gas flows indicated above, contact times of up to about $8 \mathrm{~s}$ (see Fig. 8) were achieved. $\mathrm{SO}_{2} \mathrm{~F}_{2}$ exiting the flow tube at a concentration of approximately $5 \times 10^{13}$ molecule $\mathrm{cm}^{-3}$ was detected by electron bombardment positive ion mass spectrometry (MS) at $m / z=83$. This was the strongest ion signal when the MS was operated with an electron energy of $70 \mathrm{eV}$.

\subsection{Chemicals}

$\mathrm{He}$ (Westfalen, 99.999\%), $\mathrm{N}_{2}$ (Messer 99.999), $\mathrm{O}_{2}$ (Messer, 99.998), Synthetic Air (Messer, $20.5 \% \mathrm{O}_{2}$ in $\mathrm{N}_{2}$ ), $\mathrm{N}_{2} \mathrm{O}$ (Messer, 99.5\%), $\mathrm{SO}_{2} \mathrm{~F}_{2}\left(\mathrm{ABCR}, 99 \%\right.$ ) and $\mathrm{SF}_{6}$ (Messer
$1.99 \%$ in $\mathrm{He} 99.9 \%$ ) were used without further purification. $\mathrm{O}_{3}$ was prepared using a commercial ozoniser (Ozomat), trapped on silica gel at $T=195 \mathrm{~K}$, and flushed with He to remove $\mathrm{O}_{2}$ before dilution $\left(\sim 10^{-4}\right)$ in He and storage in blackened glass bulbs. $n-\mathrm{C}_{5} \mathrm{H}_{12}$ (Aldrich "wasserfrei" $99+\%$ ) and $n-\mathrm{C}_{6} \mathrm{H}_{14}$ (neoLab >95\%) were subject to repeated freezepump-thaw cycles at $77 \mathrm{~K}$ prior to dilution and storage. Aqueous solutions for the WWFT experiments were prepared using "milli-Q" de-ionised water, with the $\mathrm{pH}$ adjusted by addition of $\mathrm{H}_{2} \mathrm{SO}_{4}$ or $\mathrm{NaOH}$.

\section{Results}

The determination of kinetic parameters for (R1-R4) are detailed in Sects. 3.1-3.3 below. As this was the first comprehensive study of the atmospheric chemistry of $\mathrm{SO}_{2} \mathrm{~F}_{2}$, comparison with literature data was rarely possible. Where possible however, the experimental methods used here were validated by the concurrent study of well-characterised processes, such as the reactions of $\mathrm{O}\left({ }^{1} \mathrm{D}\right)$ with the important atmospheric species $\mathrm{N}_{2}, \mathrm{~N}_{2} \mathrm{O}, \mathrm{H}_{2} \mathrm{O}$ and $\mathrm{SF}_{6}$. The infrared absorption spectrum of $\mathrm{SO}_{2} \mathrm{~F}_{2}$ is described in Sect. 3.4 and the uptake of $\mathrm{SO}_{2} \mathrm{~F}_{2}$ to aqueous solutions in Sect. 3.5. The atmospheric implications of the results obtained are discussed in Sect. 3.6.

\subsection{Kinetics and products of $\mathrm{O}\left({ }^{1} \mathrm{D}\right)+\mathrm{SO}_{2} \mathrm{~F}_{2}(\mathrm{R} 1)$}

\subsubsection{Rate coefficients $k_{1}(220-300 \mathrm{~K})$}

Absolute values for $k_{1}(T)$ were determined by a competitive rate method, similar to that employed by Blitz et al. (2004). This method relies on the fact that the kinetics of product formation are governed by the rate of decay of the precursor species. Specifically in this work, where the LIF detection of $\mathrm{OH}$ is used as a spectroscopic marker for $\mathrm{O}\left({ }^{1} \mathrm{D}\right)$ :

$\frac{d\left[\mathrm{O}\left({ }^{1} \mathrm{D}\right)\right]}{d t}=\frac{-d[\mathrm{OH}]}{d t}$

PLP generation (R5) of $\mathrm{O}\left({ }^{1} \mathrm{D}\right)$ in the presence of $n-\mathrm{C}_{6} \mathrm{H}_{14}$ facilitated rapid conversion (R7) of $\mathrm{O}\left({ }^{1} \mathrm{D}\right)$ to $\mathrm{OH}$. Figure 1 displays an example of an OH LIF profile recorded at $\left[\mathrm{O}_{3}\right] \approx 1 \times 10^{12},\left[n-\mathrm{C}_{6} \mathrm{H}_{14}\right]=2.1 \times 10^{13}$ molecule $\mathrm{cm}^{-3}$ and $P=42$ Torr (1 Torr $=1.333 \mathrm{mBar}$ ) of $\mathrm{He}$ (bath gas) at $T=298 \mathrm{~K}$. The open circles in Fig. 1 show an OH LIF profile, recorded upon addition of $\left[\mathrm{SO}_{2} \mathrm{~F}_{2}\right]=2.3 \times 10^{14}$ molecule $\mathrm{cm}^{-3}$ to the reaction mixture. The introduction of $\mathrm{SO}_{2} \mathrm{~F}_{2}$ results in the observation of a smaller $\mathrm{OH}$ signal, which is formed on a shorter timescale as $\mathrm{SO}_{2} \mathrm{~F}_{2}$ competes to destroy $\mathrm{O}\left({ }^{1} \mathrm{D}\right)$. Pseudo first-order conditions of both $\left[n-\mathrm{C}_{6} \mathrm{H}_{14}\right]$ and $\left[\mathrm{SO}_{2} \mathrm{~F}_{2}\right] \gg\left[\mathrm{O}\left({ }^{1} \mathrm{D}\right)\right]$ and $[\mathrm{OH}]$ applied, and the data were therefore analysed with the appropriate kinetic expression (Eq. 2):

$[\mathrm{OH}]_{t}=A \times\{\exp (-B t)-\exp (-C t)\}$ 


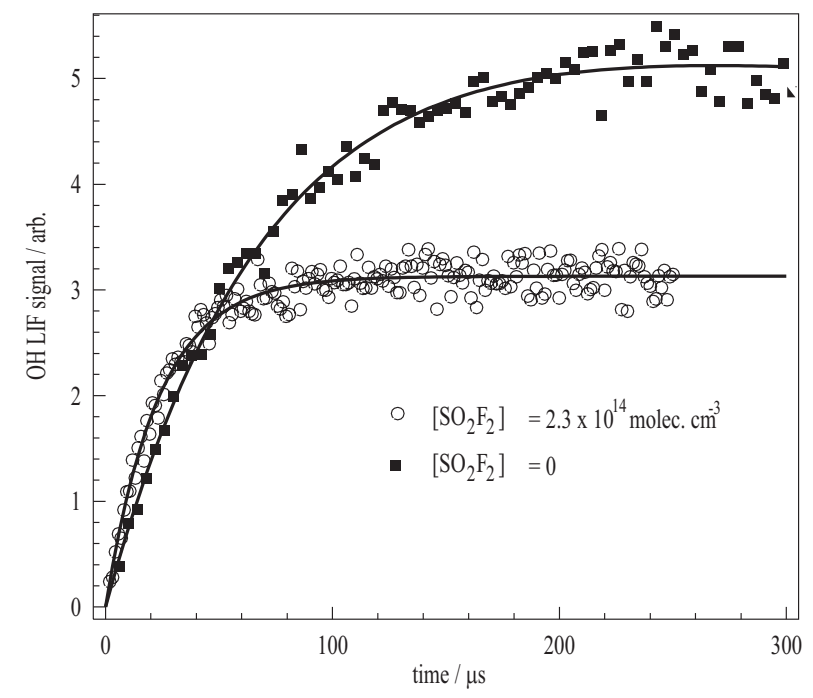

Fig. 1. $\mathrm{OH}$ LIF profiles recorded at two different $\left[\mathrm{SO}_{2} \mathrm{~F}_{2}\right]$ in determination of $k_{1}(300 \mathrm{~K})$. Experimental conditions were $P=42$ Torr, $T=300 \mathrm{~K}, \quad\left[\mathrm{O}_{3}\right]=1 \times 10^{12}$ and $\left[n-\mathrm{C}_{6} \mathrm{H}_{14}\right]=2.1 \times 10^{13}$ molecule $\mathrm{cm}^{-3}$. The solid lines are fits using expression (2) to obtain the kinetic parameter $C$.

where $A$ is proportional to the initial $\left[\mathrm{O}\left({ }^{1} \mathrm{D}\right)\right], B$ is the approximate pseudo first-order rate coefficient for $\mathrm{OH}$ loss (dominated by slow transport out of the LIF volume), and the parameter of interest $C$ is the 1st-order rate coefficient for $\mathrm{OH}$ formation (equivalent to $\mathrm{O}\left({ }^{1} \mathrm{D}\right)$ loss, see Eq. (1) above).

$$
C=k_{1}\left[\mathrm{SO}_{2} \mathrm{~F}_{2}\right]+k_{7}\left[n-\mathrm{C}_{6} \mathrm{H}_{14}\right]+k_{\text {loss_o(1D) }}
$$

The parameter $k_{\text {loss_O(1D) }}$ accounts for reaction of $\mathrm{O}\left({ }^{1} \mathrm{D}\right)$ with $\mathrm{O}_{3}$, bath-gas $(\mathrm{He})$ and trace impurities therein. Experimentally determined values of $C$ were obtained with a fixed $n-\mathrm{C}_{6} \mathrm{H}_{14}$ concentration and various values of $\left[\mathrm{SO}_{2} \mathrm{~F}_{2}\right]$ so that that a plot of $C$ versus associated $\left[\mathrm{SO}_{2} \mathrm{~F}_{2}\right]$ (Fig. 2, solid squares) has a gradient equivalent to $k_{1}(298 \mathrm{~K})$, and an intercept of $k_{7}\left[n-\mathrm{C}_{6} \mathrm{H}_{14}\right]+k_{\text {loss_O(1D) }}$ (Eq. 3). An unweighted linear fit to the dataset displayed (solid line) yields $k_{1}(298 \mathrm{~K})=(1.39 \pm 0.1) \times 10^{-10} \mathrm{~cm}^{3}$ molecule $\mathrm{s}^{-1} \mathrm{~s}^{-1}$. Experiments were repeated over the range of $218<T / \mathrm{K}<300$, using both $n-\mathrm{C}_{5} \mathrm{H}_{12}$ and $n-\mathrm{C}_{6} \mathrm{H}_{14}$ to convert $\mathrm{O}\left({ }^{1} \mathrm{D}\right)$ to $\mathrm{OH}$. Statistically similar values of $k_{1}(T)$ were obtained (Table 1 ).

The kinetic analysis was validated in 3 ways. First, in the presence of $\mathrm{SO}_{2} \mathrm{~F}_{2}, \mathrm{OH}$ profiles were recorded in which the photolysis laser energy was varied by a factor of 5 . No systematic change in $C$ was observed, indicating that secondary chemistry did not perturb the $\mathrm{OH}$ kinetics. Second, rate coefficients for the reactions of $\mathrm{O}\left({ }^{1} \mathrm{D}\right)$ with $n-\mathrm{C}_{5} \mathrm{H}_{12}$ (R6) and $n-\mathrm{C}_{6} \mathrm{H}_{14}$ (R7) were determined by recording $\mathrm{OH}$ profiles at different alkane concentrations in the absence of $\mathrm{SO}_{2} \mathrm{~F}_{2}$. The plots of parameter $C$ (obtained from fitting expression (2) to the data) versus $\left[n-\mathrm{C}_{5} \mathrm{H}_{12}\right]$ or $\left[n-\mathrm{C}_{6} \mathrm{H}_{14}\right]$ yielded $k_{6}(298 \mathrm{~K})=(5.4 \pm 0.4) \times 10^{-10} \mathrm{~cm}^{3}$ molecule ${ }^{-1} \mathrm{~s}^{-1}$ and $k_{7}$

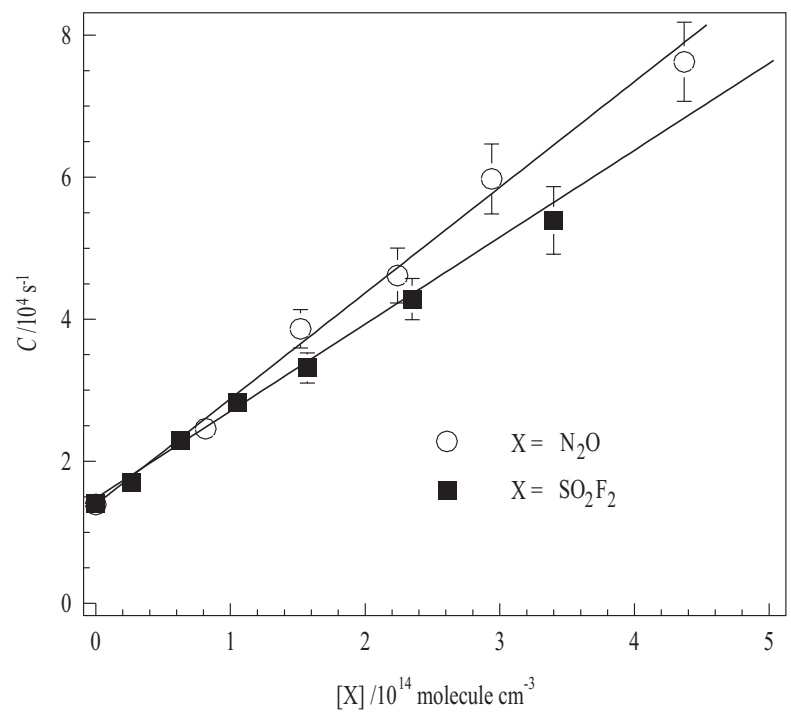

Fig. 2. Bimolecular plot of $C$ vs. $\left[\mathrm{SO}_{2} \mathrm{~F}_{2}\right]$ used to determine $k_{1}(300 \mathrm{~K})=(1.22 \pm 0.06) \times 10^{-10} \mathrm{~cm}^{3}$ molecule $\mathrm{s}^{-1}$. The intercept value of $\sim 14000 \mathrm{~s}^{-1}$ is consistent with the use of $[n$ $\left.\mathrm{C}_{6} \mathrm{H}_{14}\right]=2 \times 10^{13}$ molecule $\mathrm{cm}^{-3}$ to convert $\mathrm{O}\left({ }^{1} \mathrm{D}\right)$ to $\mathrm{OH}(\mathrm{R} 7)$. The plot also shows the results of an experiment to determine $k_{11}$ $(296 \mathrm{~K})=(1.45 \pm 0.08) \times 10^{-10} \mathrm{~cm}^{3}$ molecule $\mathrm{s}^{-1} \mathrm{~s}^{-1}$.

$(298 \mathrm{~K})=(5.8 \pm 0.5) \times 10^{-10} \mathrm{~cm}^{3}$ molecule $\mathrm{s}^{-1} \mathrm{~s}^{-1}$, in excellent agreement with the only previous absolute determinations (Dillon et al., 2007) and an evaluation of earlier relative rate determinations (Schofield, 1978). Third, the competitive rate method was employed to determine rate coefficients for the well-characterised (R10) and (R11):

$\mathrm{O}\left({ }^{1} \mathrm{D}\right)+\mathrm{N}_{2} \rightarrow \mathrm{O}\left({ }^{3} \mathrm{P}\right)+\mathrm{N}_{2}$

$\mathrm{O}\left({ }^{1} \mathrm{D}\right)+\mathrm{N}_{2} \mathrm{O} \rightarrow$ (products)

The procedure was identical to that described above, and many experiments were carried out back-to-back with the determinations of $k_{1}$. The results, listed in Table 1 and illustrated in Fig. 2 for $\mathrm{N}_{2} \mathrm{O}$, are $k_{10} \quad(298 \mathrm{~K})=(0.33 \pm 0.06) \times 10^{-10} \mathrm{~cm}^{3}$ molecule ${ }^{-1} \mathrm{~s}^{-1}$ and $k_{11}(298 \mathrm{~K})=(1.45 \pm 0.2) \times 10^{-10} \mathrm{~cm}^{3}$ molecule ${ }^{-1} \mathrm{~s}^{-1}$, which agree (within combined uncertainties) with the evaluated literature (Sander et al., 2006; Atkinson et al., 2007) and other recent determinations (Blitz et al., 2004; Dunlea and Ravishankara, 2004b; Strekowski et al., 2004; Carl, 2005; Takahashi et al., 2005). The good agreement indicates that potential problems associated with formation of vibrationally excited $\mathrm{OH}$ radicals are insignificant and give confidence in the values of $k_{1}$ obtained in this work.

In some additional experiments, $\mathrm{H}_{2} \mathrm{O}$ was used to convert $\mathrm{O}\left({ }^{1} \mathrm{D}\right)$ to $\mathrm{OH}(\mathrm{R} 8)$. The procedures detailed above were used to obtain $k_{8}$ directly, and $k_{10}\left(\mathrm{O}\left({ }^{1} \mathrm{D}\right)+\mathrm{N}_{2}\right)$. The results are in satisfactory agreement with the literature. Some experiments 
Table 1. Determination of rate coefficients for the reactions $\mathrm{O}\left({ }^{1} \mathrm{D}\right)+\mathrm{X} \rightarrow$ products.

\begin{tabular}{ccccc}
\hline $\mathrm{X}$ & $T / \mathrm{K}$ & $\mathrm{H}-$ donor & range of $[\mathrm{X}]^{\mathrm{a}}$ & $k(T)^{\mathrm{b}}$ \\
\hline $\mathrm{SO}_{2} \mathrm{~F}_{2}$ & 300 & $n-\mathrm{C}_{6} \mathrm{H}_{14}$ & $0-20.9$ & $1.29 \pm 0.20$ \\
$\mathrm{SO}_{2} \mathrm{~F}_{2}$ & 300 & $n-\mathrm{C}_{6} \mathrm{H}_{14}$ & $0-20.9$ & $1.25 \pm 0.20$ \\
$\mathrm{SO}_{2} \mathrm{~F}_{2}$ & 300 & $n-\mathrm{C}_{6} \mathrm{H}_{14}$ & $0-34.0$ & $1.22 \pm 0.06$ \\
$\mathrm{SO}_{2} \mathrm{~F}_{2}$ & 298 & $n-\mathrm{C}_{6} \mathrm{H}_{14}$ & $0-25.5$ & $1.39 \pm 0.12$ \\
$\mathrm{SO}_{2} \mathrm{~F}_{2}$ & 297 & $n-\mathrm{C}_{5} \mathrm{H}_{12}$ & $0-19.4$ & $1.20 \pm 0.20$ \\
$\mathrm{SO}_{2} \mathrm{~F}_{2}$ & 222 & $n-\mathrm{C}_{5} \mathrm{H}_{12}$ & $0-27.0$ & $1.47 \pm 0.08$ \\
$\mathrm{SO}_{2} \mathrm{~F}_{2}$ & 218 & $n-\mathrm{C}_{6} \mathrm{H}_{14}$ & $2.4-40.5$ & $1.39 \pm 0.10$ \\
$n-\mathrm{C}_{5} \mathrm{H}_{12}$ & 297 & $n-\mathrm{C}_{5} \mathrm{H}_{12}$ & $0-9.3$ & $5.4 \pm 0.4$ \\
$n-\mathrm{C}_{6} \mathrm{H}_{14}$ & 300 & $n-\mathrm{C}_{6} \mathrm{H}_{14}$ & $0-10.4$ & $5.8 \pm 0.5$ \\
$\mathrm{~N}_{2}$ & 300 & $n-\mathrm{C}_{6} \mathrm{H}_{14}$ & $0-172.0$ & $0.35 \pm 0.02$ \\
$\mathrm{~N}_{2}$ & 297 & $n-\mathrm{C}_{6} \mathrm{H}_{14}$ & $0-212.0$ & $0.33 \pm 0.02$ \\
$\mathrm{~N}_{2}$ & 297 & $n n_{n} e^{\mathrm{c}}$ & $0-277.0$ & $0.30 \pm 0.04$ \\
$\mathrm{~N}_{2}$ & 297 & $\mathrm{H}_{2} \mathrm{O}$ & $0-106.0$ & $0.38 \pm 0.05$ \\
$\mathrm{~N}_{2}$ & 297 & $n-\mathrm{C}_{6} \mathrm{H}_{14}$ & $0-212.0$ & $0.30 \pm 0.02$ \\
$\mathrm{H}_{2} \mathrm{O}$ & 297 & $\mathrm{H}_{2} \mathrm{O}$ & $0-17.8$ & $1.94 \pm 0.13$ \\
$\mathrm{~N}_{2} \mathrm{O}$ & 296 & $n-\mathrm{C}_{5} \mathrm{H}_{12}$ & $0-37.1$ & $1.45 \pm 0.08$ \\
$\mathrm{~N}_{2} \mathrm{O}$ & 296 & $n-\mathrm{C}_{5} \mathrm{H}_{12}$ & $0-49.5$ & $1.49 \pm 0.08$ \\
\hline
\end{tabular}

Notes:

In all experiments, the total pressure was held close to 42 Torr and $\mathrm{H}$ atom donors were present at $\approx 2 \times 10^{13}$ molecule $\mathrm{cm}^{-3}$.

a units of concentration $=10^{13}$ molecule $\mathrm{cm}^{-3}$;

b units for $k(T)=10^{-10} \mathrm{~cm}^{3}$ molecule $\mathrm{e}^{-1} \mathrm{~s}^{-1}$;

${ }^{c}$ no $\mathrm{H}$-atom donor was added to the reaction mixture, however $\mathrm{OH}$ was observed from reactions of $\mathrm{O}\left({ }^{1} \mathrm{D}\right)$ with impurities (e.g. $\mathrm{H}_{2} \mathrm{O}$, $\mathrm{H}_{2}$ ) in the bath gas.

were also conducted with a $\mathrm{O}\left({ }^{1} \mathrm{D}\right) / \mathrm{H}_{2} \mathrm{O} / \mathrm{SO}_{2} \mathrm{~F}_{2}$ reaction system with the aim of a further, independent measurement of $k_{1}$. However, the LIF profiles generated in the presence of $\mathrm{SO}_{2} \mathrm{~F}_{2}$ were characterised by the expected rapid $\mathrm{OH}$ formation due to $\mathrm{O}\left({ }^{1} \mathrm{D}\right)$ loss in (R1) and (R8), followed by a secondary slow $\mathrm{OH}$ formation process. The slow $\mathrm{OH}$ source was not evident in back-to-back experiments where $\mathrm{SO}_{2} \mathrm{~F}_{2}$ was absent or replaced by $\mathrm{N}_{2}$. A possible explanation for these observations is that a product of (R1), not produced in (R8) or (R10) may itself be an $\mathrm{OH}$ precursor. It appears likely that F-atoms, formed as a product of $\mathrm{SO}_{2} \mathrm{~F}_{2}$ destruction $(\mathrm{R} 1 \mathrm{~b})$ by $\mathrm{O}\left({ }^{1} \mathrm{D}\right)$, are converted by $\mathrm{H}_{2} \mathrm{O}$ to $\mathrm{OH}$ in the well-characterised (R12):

$\mathrm{F}+\mathrm{H}_{2} \mathrm{O} \rightarrow \mathrm{OH}+\mathrm{HF}$

Numerical simulation of these experiments using the evaluated literature value $k_{12}$ (298 K) $=1.4 \times 10^{-11} \mathrm{~cm}^{3}$ molecule ${ }^{-1} \mathrm{~s}^{-1} \quad$ demonstrated that (R12) could indeed account for the secondary $\mathrm{OH}$ observed in the presence of $\mathrm{SO}_{2} \mathrm{~F}_{2}$ if a yield of $\approx 20 \%$ F-atoms from (R1) was assumed. This result, implying that $\mathrm{SO}_{2} \mathrm{~F}_{2}$ is destroyed in (R1), is only semi-quantitative, and prompted experiments (see Sects. 3.1.2 and 3.1.3) to quantify the relative importance of reaction channels (R1a) and (R1b).

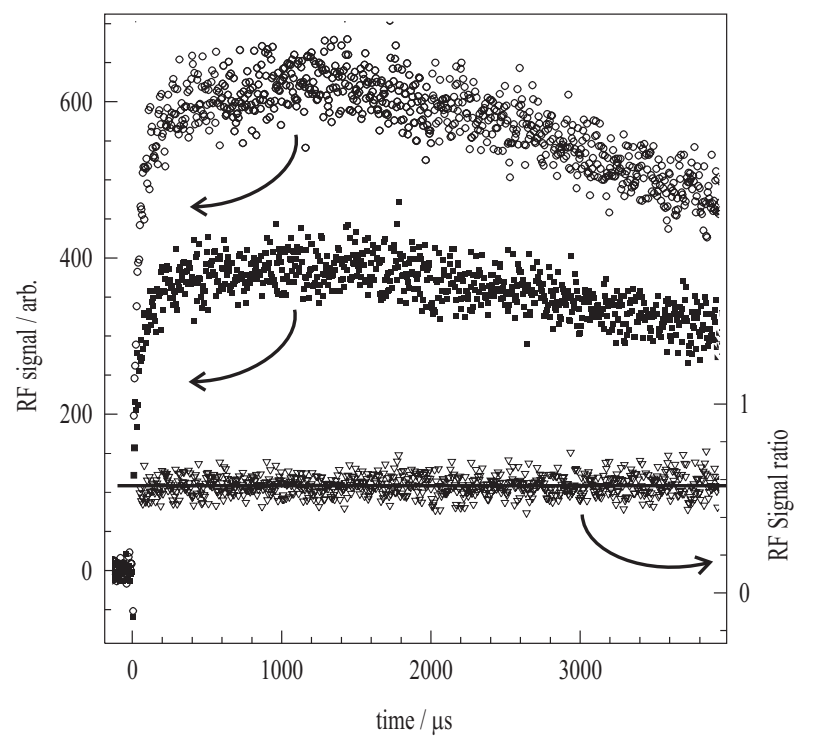

Fig. 3. $\mathrm{O}\left({ }^{3} \mathrm{P}\right)$ generated in $\mathrm{O}\left({ }^{1} \mathrm{D}\right)+\mathrm{SO}_{2} \mathrm{~F}_{2} \rightarrow$ products $(\mathrm{R} 1)$ with $\left[\mathrm{SO}_{2} \mathrm{~F}_{2}\right]=1.4 \times 10^{14}$ molecule $\mathrm{cm}^{-3}$ (middle trace). Also displayed is the $\mathrm{O}\left({ }^{3} \mathrm{P}\right) \mathrm{RF}$ signal obtained in a back-to-back experiment in which $\mathrm{O}\left({ }^{1} \mathrm{D}\right)$ reacts $(\mathrm{R} 10)$ with a kinetically similar $\left[\mathrm{N}_{2}\right]=5.6 \times 10^{14}$ molecule $\mathrm{cm}^{-3}$ (upper trace). As the yield of $\mathrm{O}\left({ }^{3} \mathrm{P}\right)$ in $(\mathrm{R} 10)$ is known to be unity, the yield of $\mathrm{O}\left({ }^{3} \mathrm{P}\right)$ in $(\mathrm{R} 1)=k_{1 a} / k_{1}=(0.56 \pm 0.01)$ was calculated from the ratio of $\mathrm{RF}$ signal intensities (lower trace) plotted on the right axis.

Although there are no experimental data with which to compare our value for $k_{1}$, we note that the result is consistent with the predicted value of $(1.1 \pm 0.8) \times 10^{-10} \mathrm{~cm}^{3}$ molecule ${ }^{-1} \mathrm{~s}^{-1}$ based on an ionisation potential/collision cross section relationship presented by Dillon et al. (2007).

\subsection{2 $\mathrm{O}\left({ }^{3} \mathrm{P}\right)$ product yield}

Figure 3 displays an example of an $\mathrm{O}\left({ }^{3} \mathrm{P}\right)$ RF profile $\left(\mathrm{RF}_{\mathrm{SO}_{2} \mathrm{~F}_{2}}\right)$ obtained following photolysis of $\mathrm{O}_{3}$ (R5) in the presence of $\left[\mathrm{SO}_{2} \mathrm{~F}_{2}\right]=1.4 \times 10^{14}$ molecule $\mathrm{cm}^{-3}$ at $P=42$ Torr and $T=296 \mathrm{~K}$. The yield $\left(k_{1 a} / k_{1}\right)$ of $\mathrm{O}\left({ }^{3} \mathrm{P}\right)$ from (R1) was determined by using the reaction of $\mathrm{O}\left({ }^{1} \mathrm{D}\right)$ with $\mathrm{N}_{2}$ (R10), for which the unity yield of $\mathrm{O}\left({ }^{3} \mathrm{P}\right)$ is well established, to calibrate the data. The $\mathrm{SO}_{2} \mathrm{~F}_{2}$ was replaced by a kinetically matched amount of $\mathrm{N}_{2}\left(k_{1}\left[\mathrm{SO}_{2} \mathrm{~F}_{2}\right]=k_{10}\left[\mathrm{~N}_{2}\right]\right)$ and the $\mathrm{RF}$ signal (see Fig. 3 open circles) from (R10), $\mathrm{RF}_{\mathrm{N} 2}$ was then recorded. RF signals $\left(\mathrm{RF}_{0}\right)$ were also obtained in the absence of $\mathrm{SO}_{2} \mathrm{~F}_{2}$ or $\mathrm{N}_{2}$, to quantify the background level of $\mathrm{O}\left({ }^{3} \mathrm{P}\right)$ produced directly from $\mathrm{O}_{3}$ photolysis (Dunlea et al., 2004) and by reactions of $\mathrm{O}\left({ }^{1} \mathrm{D}\right)$ with impurities $\left(\mathrm{N}_{2}\right.$ or $\mathrm{O}_{2}$ in the bath gas He). These 3 back-to-back datasets were used to generate $\mathrm{RF}_{\text {ratio }}$, the (corrected for background) ratio of $\mathrm{RF}$ signals according to expression (2):

$\mathrm{RF}_{\text {ratio }}=\frac{\mathrm{RF}_{\mathrm{SO}_{2} \mathrm{~F}_{2}-\mathrm{BG}}}{\mathrm{RF}_{\mathrm{N}_{2}}-\mathrm{BG}}$ 
Table 2. Determination of the $\mathrm{O}\left({ }^{3} \mathrm{P}\right)$ product yield $\left(k_{1 a} / k_{1}\right)$ in $(\mathrm{R} 1)$.

\begin{tabular}{ccccc}
\hline$T / \mathrm{K}$ & {$\left[\mathrm{SO}_{2} \mathrm{~F}_{2}\right]^{\mathrm{a}}$} & {$\left[\mathrm{N}_{2}\right]^{\mathrm{a}}$} & correction $^{\mathrm{b}}$ & $k_{1 a} / k_{1}$ \\
\hline 296 & 7.6 & 30.8 & $15 \%$ & $0.52 \pm 0.01$ \\
296 & 13.8 & 56.0 & $10 \%$ & $0.57 \pm 0.01$ \\
296 & 4.6 & 19.0 & $20 \%$ & $0.57 \pm 0.01$ \\
296 & 11.0 & 44.0 & $11 \%$ & $0.55 \pm 0.01$ \\
296 & 6.0 & 25.0 & $16 \%$ & $0.55 \pm 0.01$ \\
225 & 9.1 & 37.0 & $15 \%$ & $0.58 \pm 0.01$ \\
225 & 16.3 & 53.0 & $10 \%$ & $0.54 \pm 0.01$ \\
225 & 16.5 & 66.0 & $8 \%$ & $0.55 \pm 0.02$ \\
225 & 13.2 & 45.0 & $12 \%$ & $0.54 \pm 0.01$ \\
\hline
\end{tabular}

Notes:

$\mathrm{a}$ in units of $10^{13}$ molecule $\mathrm{cm}^{-3}$

b Correction for "background" $\mathrm{O}\left({ }^{3} \mathrm{P}\right)$ according to Eq. (4), see text for details.

where

$\mathrm{BG}=\mathrm{RF}_{0} \times \frac{k_{\text {loss_O }(1 \mathrm{D})}}{k_{1}\left[\mathrm{SO}_{2} \mathrm{~F}_{2}\right]}=\mathrm{RF}_{0} \times \frac{k_{\text {loss_O }\left({ }^{1} \mathrm{D}\right)}}{k_{10}\left[\mathrm{~N}_{2}\right]}$

Figure 3 shows the resulting time-resolved $\mathrm{RF}_{\text {ratio, }}$, which is equivalent to the product yield for $\mathrm{O}\left({ }^{3} \mathrm{P}\right)$ from (R1): $k_{1 a} / k_{1}=(0.56 \pm 0.01)$. The process was repeated for different kinetically matched amounts of $\mathrm{SO}_{2} \mathrm{~F}_{2}$ and $\mathrm{N}_{2}$, with the corrections for background $\mathrm{O}\left({ }^{3} \mathrm{P}\right)$ (never more than $20 \%$ ) smaller for larger $\left[\mathrm{SO}_{2} \mathrm{~F}_{2}\right]$. The results are displayed in Table 2 , which shows a consistent value of $k_{1 a} / k_{1}=(0.55 \pm 0.04)$ at around ambient temperature. Similar results were obtained at $T=225 \mathrm{~K}$.

$\mathrm{RF}$ detection of $\mathrm{O}\left({ }^{3} \mathrm{P}\right)$ was found to be less suitable for the determination of the absolute rate coefficients, $k_{1}(T)$. As is evident from Fig. 3, the data close to $t=0$, where the fast (R1) occurs, is not particularly well resolved, and in some experiments was distorted by a strong radio-frequency signal from the excimer laser pulse.

\subsubsection{Relative rate determinations of $k_{1 \mathrm{~b}}$}

Mixtures containing $\mathrm{SO}_{2} \mathrm{~F}_{2}$ and $\mathrm{N}_{2} \mathrm{O}$ (both at concentrations of $9-15 \times 10^{14}$ molecule $\mathrm{cm}^{-3}$ ) and $\mathrm{O}_{3}$ in He bath gas were photolysed for between 15 and $300 \mathrm{~s}$ to result in measurable changes (up to $15 \%$ ) in the $\mathrm{SO}_{2} \mathrm{~F}_{2}$ and $\mathrm{N}_{2} \mathrm{O}$ concentrations. The fractional depletion of both species was limited by the concentration of $\mathrm{O}_{3}$, which was completely destroyed, resulting in the disappearance of its $1042 \mathrm{~cm}^{-1}$ absorption feature. The initial $\mathrm{O}_{3}$ concentration (this parameter is not needed in the kinetic analysis) could not be monitored as accessible absorption bands were optically black.

The intense absorption feature of $\mathrm{SO}_{2} \mathrm{~F}_{2}$ centred at $1504 \mathrm{~cm}^{-1}$ was generally used for determination of the $\mathrm{SO}_{2} \mathrm{~F}_{2}$ depletion factor after photolysis. The depletion factor was obtained by least-squares fitting of the pre- and post-
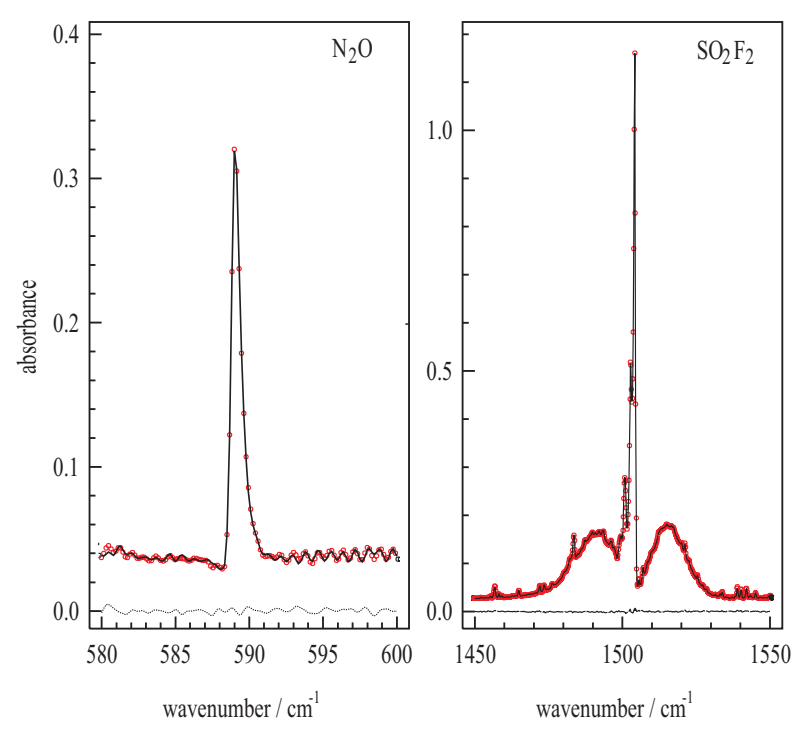

Fig. 4. Raw FTIR spectral data for $\mathrm{SO}_{2} \mathrm{~F}_{2}$ and $\mathrm{N}_{2} \mathrm{O}$ in relative rate studies. The data points (circles) were determined after photolysis, the solid lines are scaled reference spectra (obtained before photolysis) with the scaling factor (depletion factor) obtained by least squares fitting. The broken lines are the fit residuals.

photolysis spectra in the $1438-1566 \mathrm{~cm}^{-1}$ range. The relative change in $\mathrm{N}_{2} \mathrm{O}$ over the same period was obtained in a similar manner using the single absorption feature around $590 \mathrm{~cm}^{-1}$. Fitted $\mathrm{N}_{2} \mathrm{O}$ and $\mathrm{SO}_{2} \mathrm{~F}_{2}$ spectra, showing the spectral ranges used and the fit-residuals are given in Fig. 4. Use of the stronger $\mathrm{N}_{2} \mathrm{O}$ feature at $\approx 1285 \mathrm{~cm}^{-1}$ was not possible due to overlap with a $\mathrm{SO}_{2} \mathrm{~F}_{2}$ absorption band. Owing to the use of several data points the statistical error $(2 \sigma)$ in determination of the relative changes in $\mathrm{SO}_{2}$ or $\mathrm{N}_{2} \mathrm{O}$ concentration was $\approx 6 \times 10^{-4}$ and $\approx 5 \times 10^{-3}$, respectively.

Use of parts (or all of) the triplet feature of $\mathrm{SO}_{2} \mathrm{~F}_{2}$ between 530 and $560 \mathrm{~cm}^{-1}$ (see complete IR spectrum presented in Sect. 3.4) gave similar results but with reduced precision.

In the absence of $\mathrm{O}_{3}$, neither $\mathrm{N}_{2} \mathrm{O}$ nor $\mathrm{SO}_{2} \mathrm{~F}_{2}$ were measurably depleted by photolysis, nor by dark/wall losses. Additional support for the contention that both $\mathrm{N}_{2} \mathrm{O}$ and $\mathrm{SO}_{2} \mathrm{~F}_{2}$ were removed only by reaction with $\mathrm{O}\left({ }^{1} \mathrm{D}\right)$ and that mixing/segregation effects could be ruled out, was obtained by conducting experiments in which $\mathrm{SO}_{2} \mathrm{~F}_{2}$ was replaced by $\mathrm{SF}_{6}$. In this case, although $\mathrm{N}_{2} \mathrm{O}$ was depleted, $\mathrm{SF}_{6}$, a molecule with very low reactivity to $\mathrm{O}\left({ }^{1} \mathrm{D}\right)$ (Sander et al., 2006) was unchanged.

The relative changes in $\mathrm{SO}_{2} \mathrm{~F}_{2}$ and $\mathrm{N}_{2} \mathrm{O}$ concentrations were analysed using the standard relation

$\ln \left(\frac{\left[\mathrm{SO}_{2} \mathrm{~F}_{2}\right]_{0}}{\left[\mathrm{SO}_{2} \mathrm{~F}_{2}\right]}\right)=\frac{k_{1}}{k_{11}} \cdot \ln \left(\frac{\left[\mathrm{N}_{2} \mathrm{O}\right]_{0}}{\left[\mathrm{~N}_{2} \mathrm{O}\right]}\right)$

The complete data set is displayed in Fig. 5, in which the solid line is the least squares fit to the data as described 


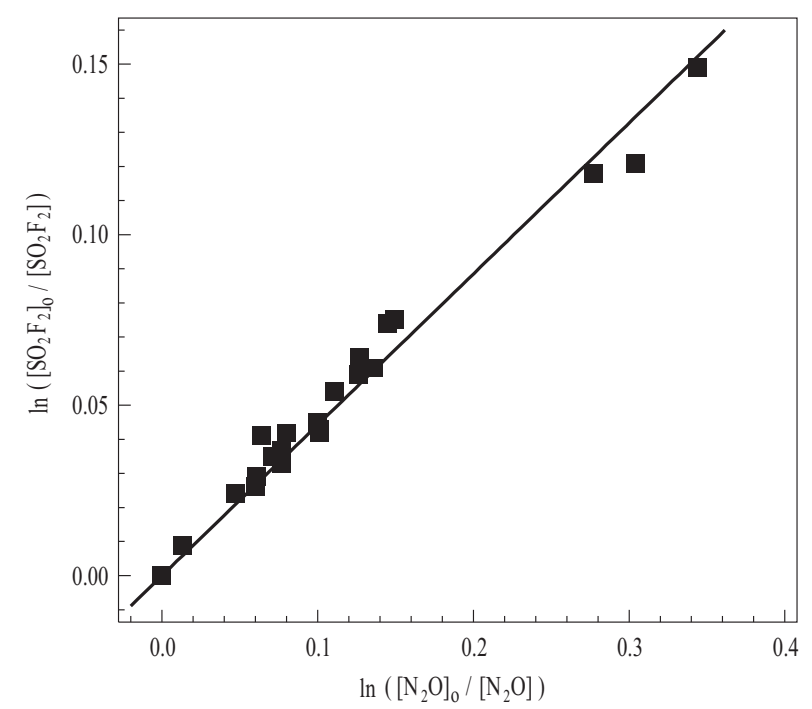

Fig. 5. Relative rate plot of depletion of $\mathrm{N}_{2} \mathrm{O}$ (reference compound) versus depletion of $\mathrm{SO}_{2} \mathrm{~F}_{2}$ to determine the ratio $k_{1 \mathrm{~b}} / k_{11}=(0.44 \pm 0.01)$ from a linear fit to the data with the intercept forced through zero.

by Eq. (5). The slope of the fit line gives the rate constant ratio $k_{1} / k_{11}=(0.411 \pm 0.012)$. Using a rate coefficient for reaction of $\mathrm{N}_{2} \mathrm{O}$ with $\mathrm{O}\left({ }^{1} \mathrm{D}\right)$ of $1.4 \times 10^{-10}$ molecule $\mathrm{cm}^{-3}$, from recent work (Dunlea and Ravishankara, 2004a; Carl, 2005; Takahashi et al., 2005) and from this study, $k_{1} / k_{11}$ can be converted to an absolute rate coefficient; $k_{1 \mathrm{~b}}=(5.8 \pm 0.01) \times 10^{-11} \mathrm{~cm}^{3}$ molecule ${ }^{-1} \mathrm{~s}^{-1}$. Since in this system no evidence was found for interference from unwanted photolysis and/or dark reactions we estimate that our relative ratio is accurate within $\sim 10 \%$ to which we add the error propagated from the reference reaction, also estimated at $10 \%$. Accordingly, the present determination of $k_{1 \mathrm{~b}}$ is $(5.8 \pm 0.8) \times 10^{-11} \mathrm{~cm}^{3}$ molecule $\mathrm{e}^{-1} \mathrm{~s}^{-1}$. This result is in good agreement with the value calculated from the results obtained above of overall rate coefficient $k_{1}=(1.3 \pm 0.2) \times 10^{-10} \mathrm{~cm}^{3}$ molecule ${ }^{-1} \mathrm{~s}^{-1}$ and product yield of $\mathrm{O}\left({ }^{3} \mathrm{P}\right) \quad \alpha=0.55 \pm 0.04$, whereby $k_{1 \mathrm{~b}}=(1-\alpha) \times k_{1}=(5.9 \pm 1.0) \times 10^{-11} \mathrm{~cm}^{3}$ molecule ${ }^{-1} \mathrm{~s}^{-1}$.

The infra-red spectra obtained following photolysis were inspected for formation of IR-active products including $\mathrm{NO}$, $\mathrm{SO}_{2}, \mathrm{FNO}, \mathrm{FNO}_{2}$ and $\mathrm{SOF}_{2}$, none of which were observed. We have presented evidence (Sect. 3.1.1) that $\mathrm{F}$ atoms are formed in the reaction of $\mathrm{O}\left({ }^{1} \mathrm{D}\right)$ with $\mathrm{SO}_{2} \mathrm{~F}_{2}$. The fate of $\mathrm{F}$ atoms in the relative rate studies would be reaction with $\mathrm{O}_{3}$ to form $\mathrm{FO}$, which, in the absence of a rapid reaction with $\mathrm{O}_{3}$ (Atkinson et al., 2007) may undergo self reaction to reform $\mathrm{F}$ atoms, thus contributing to $\mathrm{O}_{3}$ depletion but not to product formation. The identity (and fate) of the sulphur containing product remains unknown.

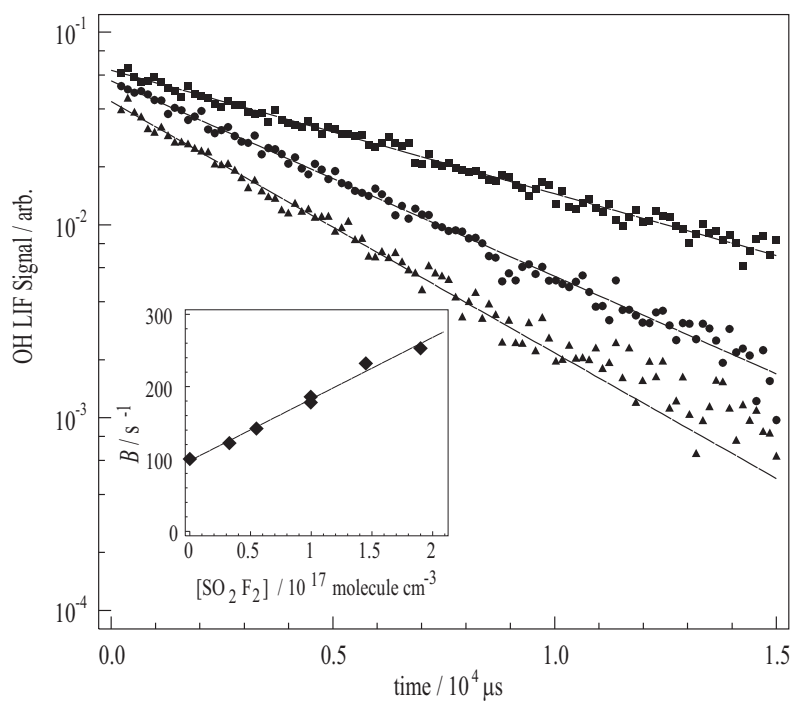

Fig. 6. Determination of $k_{2}(T=294 \mathrm{~K})$ for reaction of $\mathrm{OH}+\mathrm{SO}_{2} \mathrm{~F}_{2} \rightarrow$ products. The three $\mathrm{OH}$ LIF profiles show data collected at: $\left[\mathrm{SO}_{2} \mathrm{~F}_{2}\right] /$ molecule $\mathrm{cm}^{-3}=0$ (upper trace), $9.96 \times 10^{16}$ (middle trace) and $19.0 \times 10^{16}$ (lower trace). The straight lines depict fits with expression (6) to obtain values of parameter $B$. The insert shows the plot of $B$ versus $\left[\mathrm{SO}_{2} \mathrm{~F}_{2}\right]$ to yield $k_{2}$ $(294 \mathrm{~K})=(8.5 \pm 0.8) \times 10^{-16} \mathrm{~cm}^{3}$ molecule $\mathrm{s}^{-1} \mathrm{~s}^{-1}$.

\subsection{Kinetics of $\mathrm{OH}+\mathrm{SO}_{2} \mathrm{~F}_{2} \rightarrow$ products (R2)}

Figure 6 displays OH LIF profiles obtained following photolysis of $\mathrm{H}_{2} \mathrm{O}_{2}$ (R9) at 3 different $\left[\mathrm{SO}_{2} \mathrm{~F}_{2}\right]$. The experiments were conducted using $\left[\mathrm{H}_{2} \mathrm{O}_{2}\right]=5 \times 10^{13}$ molecule $\mathrm{cm}^{-3}$ at $P=300$ Torr $\left(\mathrm{N}_{2}\right)$ and $T=294 \mathrm{~K}$. Note that large $\left[\mathrm{SO}_{2} \mathrm{~F}_{2}\right]$ of up to $2 \times 10^{17}$ molecule $\mathrm{cm}^{-3}$ were used to significantly perturb the $\mathrm{OH}$ decay kinetics. Pseudo 1st-order conditions of $\left[\mathrm{SO}_{2} \mathrm{~F}_{2}\right]$ and $\left[\mathrm{H}_{2} \mathrm{O}_{2}\right] \gg[\mathrm{OH}]$ applied, therefore a simple expression was used to analyse the data. Since the $\mathrm{OH}$ was formed pseudo-instantaneously in the laser flash $C$ approaches $\infty$ and expression (2) reduces to:

$[\mathrm{OH}]_{t}=A \times \exp (-B t)$

The insert in Fig. 6 shows the plot of the parameter of interest $B$ (the pseudo first-order rate coefficient for $\mathrm{OH}$ decay) versus $\left[\mathrm{SO}_{2} \mathrm{~F}_{2}\right]$, to obtain $k_{2}$ $(294 \mathrm{~K})=(8.5 \pm 0.8) \times 10^{-16} \mathrm{~cm}^{3}$ molecule ${ }^{-1} \mathrm{~s}^{-1}$ from an unweighted linear fit to the data. Note that the intercept value of around $100 \mathrm{~s}^{-1}$ is consistent with slow loss of $\mathrm{OH}$ (in the absence of $\mathrm{SO}_{2} \mathrm{~F}_{2}$ and associated impurities) due to reaction with the precursor $\mathrm{H}_{2} \mathrm{O}_{2}$ and diffusion/transport processes. It is entirely possible that the true value of $k_{2}$ is considerably smaller than this determination, as the sample of $\mathrm{SO}_{2} \mathrm{~F}_{2}$ used in this work was of a quoted purity of $99 \%$. If the (unknown) impurities of up to $1 \%$ react with $\mathrm{OH}$ with a rate coefficient of around $1 \times 10^{-13} \mathrm{~cm}^{3}$ molecule ${ }^{-1} \mathrm{~s}^{-1}$ they could account for all of the $\mathrm{OH}$ reactivity observed 


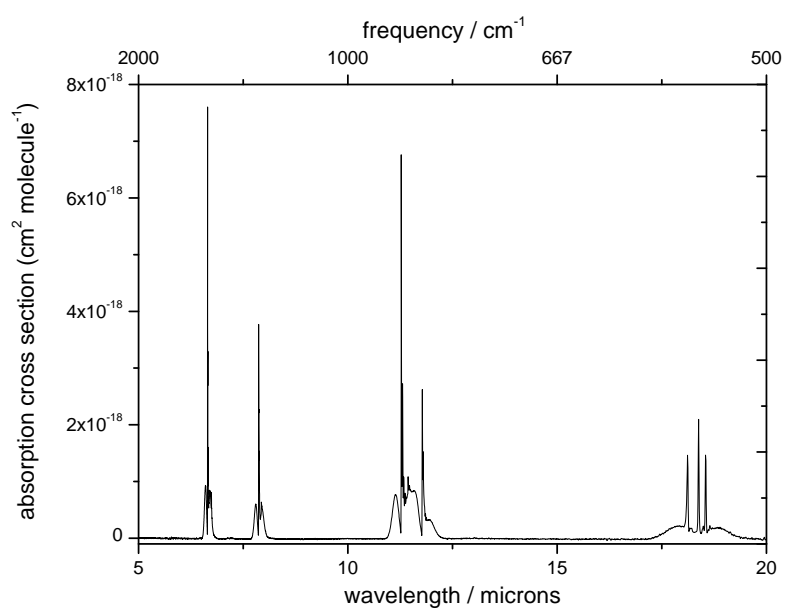

Fig. 7. The FTIR spectrum of $\mathrm{SO}_{2} \mathrm{~F}_{2}$ at $0.5 \mathrm{~cm}^{-1}$ resolution. The strong absorption feature around $1500 \mathrm{~cm}^{-1}$ was used in the relative rate study. Integrated band intensities are listed in Table 3.

in these experiments. Accordingly, based on the results of these experiments, we quote a conservative upper limit of $k_{2}(294 \mathrm{~K})<1 \times 10^{-15} \mathrm{~cm}^{3}$ molecule ${ }^{-1} \mathrm{~s}^{-1}$. We note that a considerable energetic barrier to product formation is anticipated, as strong S-F $\left(\sim 280 \mathrm{~kJ} \mathrm{~mol}^{-1}\right)$ or $\mathrm{S}=\mathrm{O}$ $\left(\sim 520 \mathrm{~kJ} \mathrm{~mol}^{-1}\right)$ bonds must be broken if $\mathrm{SO}_{2} \mathrm{~F}_{2}$ is to be destroyed in (R2). Reactions proceeding over such a barrier are characterised by an Arrhenius-type temperature dependence in $k_{2}$, which indicates that (R2) would proceed at a smaller rate at the much lower temperatures found throughout the troposphere above the boundary layer.

\subsection{Kinetics of $\mathrm{O}_{3}+\mathrm{SO}_{2} \mathrm{~F}_{2} \rightarrow$ products ( $\mathrm{R} 3$ )}

In the course of the experimental study of (R1) it was noted that $\mathrm{O}_{3}$ stored in blackened glass bulbs had a half-life of $\approx 14$ days. To test whether the (R3) proceeds with an appreciable rate, a bulb was prepared in which an excess (5 Torr) of $\mathrm{SO}_{2} \mathrm{~F}_{2}$ was added to a bulb containing 2 Torr of $\mathrm{O}_{3}$ at a total pressure of 1000 Torr (synthetic air). The absorption cells and monochromator of the PLP-LIF apparatus were used to regularly monitor $\left[\mathrm{O}_{3}\right]$ in samples taken from the mixture over the course of 3 weeks. No evidence for (R3) was observed, with $\mathrm{O}_{3}$ loss proceeding at a similar rate to that observed in the absence of $\mathrm{SO}_{2} \mathrm{~F}_{2}$. An upper limit of $k_{3}(294 \mathrm{~K})<1 \times 10^{-23} \mathrm{~cm}^{3}$ molecule ${ }^{-1} \mathrm{~s}^{-1}$ was estimated by assuming that all of the observed loss of $\mathrm{O}_{3}$ was due to (R3).

\subsection{The FTIR spectrum of $\mathrm{SO}_{2} \mathrm{~F}_{2}$}

The $0.5 \mathrm{~cm}^{-1}$ resolution, infra-red absorption spectrum of $\mathrm{SO}_{2} \mathrm{~F}_{2}$ between $\approx 6$ and $20 \mu \mathrm{m}$ is displayed in Fig. 7. The major absorption bands at 1504.3, 1270.9, 887.0, 849.2, $551.9,544.1$ and $539.2 \mathrm{~cm}^{-1}$ were observed to obey the Beer-Lambert expression for $\mathrm{SO}_{2} \mathrm{~F}_{2}$ pressures up to $\approx 1$ Torr (in a bath gas pressure of between 40 and 100 Torr). The accuracy of the absorption cross sections is expected to be determined largely by the measurement of the cell pressure and the mixing ratio in the storage bulb and should not be worse than $\pm 5 \%$. At $0.5 \mathrm{~cm}^{-1}$ resolution, the strongest absorption features are at 1504.3 and $887 \mathrm{~cm}^{-1}$, which have peak cross sections of 7.6 and $6.8 \times 10^{-18} \mathrm{~cm}^{2}$ molecule ${ }^{-1}$, respectively and no rotational structure in the $\mathrm{P}$ and $\mathrm{R}$ envelopes is observed. At a resolution of $0.1 \mathrm{~cm}^{-1}$, Q-branch splitting of the $1504.3 \mathrm{~cm}^{-1}$ feature is more clearly observed and the peak cross section at this frequency increases to $\approx 1.1 \times 10^{-17} \mathrm{~cm}^{2}$ molecule ${ }^{-1}$. The absorption features at $887.0 \mathrm{~cm}^{-1}$ (S-F stretch), $1270.4 \mathrm{~cm}^{-1}$ (S-O stretch) and $1504.3 \mathrm{~cm}^{-1}$ (S-O stretch) display rotational fine structure at the higher resolution. We note that the band positions and shapes are in good agreement with the spectrum reported in the "NIST Chemistry WebBook" (NIST Chemistry WebBook, 2005). For the purpose of estimation of the integrated band strengths of $\mathrm{SO}_{2} \mathrm{~F}_{2}$ the $0.5 \mathrm{~cm}^{-1}$ resolution spectrum is used. Integrated band strengths $(S)$ were calculated from:

$S=\left(\frac{1}{p l}\right) \int_{v 1}^{v 2} \ln \left(\frac{I o(v)}{I(v)}\right) d v$

where $p$ is the pressure of $\mathrm{SO}_{2} \mathrm{~F}_{2}$ (atm), $l$ is the optical pathlength $(\mathrm{cm})$ and $I o(v)$ and $I(v)$ are the intensities of transmitted radiation at wavenumber $v$ with and without $\mathrm{SO}_{2} \mathrm{~F}_{2}$, respectively. The results are listed in Table 3. As a test of our method, the integrated band intensity of $\mathrm{SF}_{6}$ was also determined using the same experimental set up to return a value of $S\left(\mathrm{SF}_{6}\right)=4750 \mathrm{~cm}^{-2} \mathrm{~atm}^{-1}$ for the $948 \mathrm{~cm}^{-1}$ absorption band. This value is in good agreement with a number of previous determinations (see Ko et al., 1993, for references). We are unaware of published integrated band strengths for $\mathrm{SO}_{2} \mathrm{~F}_{2}$ with which to compare our data.

\subsection{Uptake of $\mathrm{SO}_{2} \mathrm{~F}_{2}$ onto aqueous surfaces (R4)}

Despite the use of long contact times and variation of the $\mathrm{pH}$ between $\approx 2$ and 12 no loss of $\mathrm{SO}_{2} \mathrm{~F}_{2}$ was observed, indicating a lack of irreversible loss processes and/or low solubility. The datapoints at individual contact times are summarised in Fig. 8, the solid fit lines being fits to the data of the form:

$S_{t}=S_{o} \exp \left(-k_{\mathrm{obs}} t\right)$

where $t$ is the contact time, $S_{o}$ and $S_{t}$ are the signal of $\mathrm{SO}_{2} \mathrm{~F}_{2}$ at time $=$ zero and $t$, respectively and $k_{\mathrm{obs}}$ is the pseudo firstorder removal constant. The errors associated with each data point are of the order of $0.3 \%$ of the signal, and considerably smaller than the symbols in Fig. 8. The small errors, obtained by prolonged integration of the signal $(\approx 100 \mathrm{~s})$ at each contact time, were taken into account whilst performing weighted least squares fitting of the data. The values of $k_{\text {obs }}$ obtained were: $(9.5 \pm 5) \times 10^{-4},(10 \pm 4) \times 10^{-4}$ and $(5 \pm 4) \times 10^{-4}$ at $\mathrm{pH}$ values of $4.5,12$ and 2 , respectively. These values of $k_{\mathrm{obs}}$ are close to the lower limit of first-order 
Table 3. Integrated band strengths for $\mathrm{SO}_{2} \mathrm{~F}_{2}$.

\begin{tabular}{lllll}
\hline$v\left(\mathrm{~cm}^{-1}\right)$ & 1504.3 & 1270.9 & $849.2,887.0$ & $551.9,544.1,539.2$ \\
$\lambda(\mu \mathrm{m})$ & 6.648 & 7.868 & $11.78,11.27$ & $18.12,18.38,18.55$ \\
\hline Range $\left(\mathrm{cm}^{-1}\right)$ & $1455-1540$ & $1220-1310$ & $810-920$ & $500-595$ \\
$S\left(\mathrm{~cm}^{-1}\left[\mathrm{~cm} \mathrm{~atm}^{-1}\right)\right.$ & 984 & 616 & 1394 & 343 \\
\hline
\end{tabular}

removal constants measurable with this apparatus, which is determined by signal noise. $k_{\text {obs }}$ is related to the experimental uptake coefficient, $\gamma_{\text {expt }}$, via:

$\gamma_{\text {expt }}=\frac{2 \cdot r \cdot k_{\mathrm{obs}}}{\bar{c}}$

where $\gamma_{\text {expt }}$ is the experimentally derived, net ratio of collisions with the aqueous surface which remove $\mathrm{SO}_{2} \mathrm{~F}_{2}$ from the gas phase, to the total number of collisions, $r$ is the radius of the reactor $(0.775 \mathrm{~cm})$ and $\bar{c}$ is the mean thermal velocity $\left(24060 \mathrm{~cm} \mathrm{~s}^{-1}\right.$ for $\mathrm{SO}_{2} \mathrm{~F}_{2}$ at $\left.277 \mathrm{~K}\right)$ derived from the Maxwell equation. From the fitted values of $k_{\mathrm{obs}}$ and Eq. (9), we derive upper limits to $\gamma_{\text {expt }}$ of $6-9 \times 10^{-8}$ depending on $\mathrm{pH}$. Consideration of possible systematic errors associated with calculation of the contact time (via flow rates and pressure measurements) leads us to present an upper limit of $\gamma_{\text {expt }}<1 \times 10^{-7}$ for all experiments.

This result can be compared to the data of Cady and Misra (1974) who measured solubility and hydrolysis rates in alkaline solution. The rate coefficient for reaction of $\mathrm{SO}_{2} \mathrm{~F}_{2}$ with $\mathrm{OH}^{-}$was described by $k_{\mathrm{OH}^{-}}=1.67 \times 10^{12} \exp (-6593 / \mathrm{T}) \mathrm{Lmol}^{-1} \mathrm{~s}^{-1}$ which results in $k_{\mathrm{OH}^{-}}=77 \mathrm{Lmol}^{-1} \mathrm{~s}^{-1}$ at the temperature of our experiments. The solubility $(H)$ of $\mathrm{SO}_{2} \mathrm{~F}_{2}$ was given as $2.2 \times 10^{-2} \mathrm{~mol} \mathrm{~L}^{-1} \mathrm{~atm}^{-1}$ at $273 \mathrm{~K}$. If the rate of removal of gas-phase $\mathrm{SO}_{2} \mathrm{~F}_{2}$ is limited by reaction in solution these parameters can be related to the experimental uptake coefficient via:

$$
\frac{1}{\gamma_{\text {expt }}}=\frac{1}{\alpha}+\frac{1}{\gamma_{\text {react }}}
$$

with

$\gamma_{\text {react }}=\frac{4 H R T}{\bar{c}} \sqrt{D_{l} \cdot k_{\mathrm{OH}^{-}}[\mathrm{OH}]}$

$\alpha$ is the accommodation coefficient, $D_{l}$ is the aqueous phase diffusion coefficient, which is close to $2 \times 10^{-5} \mathrm{~cm}^{2} \mathrm{~s}^{-1}$ for neutral, closed shell species in aqueous solutions at ambient temperatures (Seinfeld, 1986). Taking the literature values of $H$ and $k_{\mathrm{OH}^{-}}$(Cady and Misra, 1974) and the concentration $\left(1 \times 10^{-2} \mathrm{M}\right)$ of $\mathrm{OH}^{-}$from our experiment at $\mathrm{pH}=12$ gives $\gamma_{\text {react }} \approx 2 \times 10^{-7}$. As the contribution to $\gamma_{\text {expt }}$ from the accommodation coefficient $\alpha$ (which is probably between $1 \times 10^{-3}$ and 1) will be small, $\gamma_{\text {react }} \approx \gamma_{\text {expt }}$. The calculated value of $\gamma$ is thus in acceptable agreement with the measured upper limit to $\gamma_{\text {react }}$ from the WWFT experiments. Cady and Misra

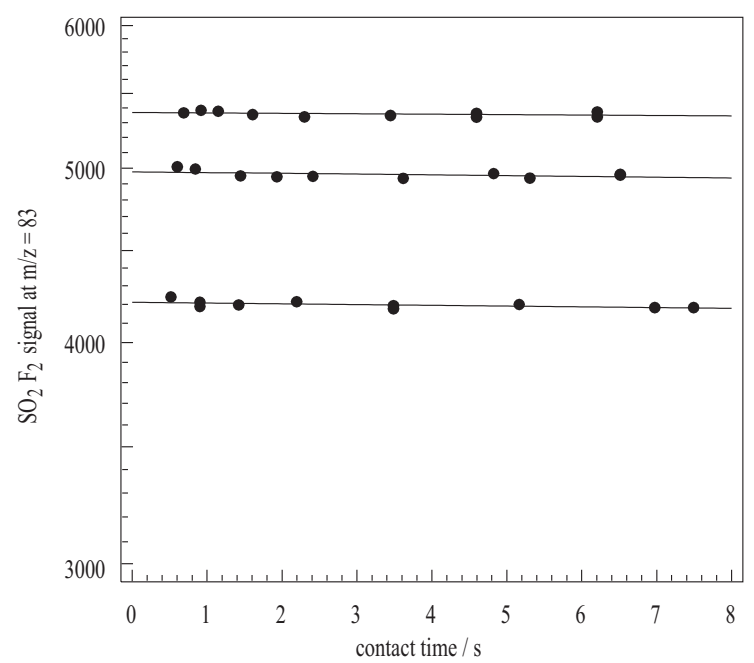

Fig. 8. The uptake of $\mathrm{SO}_{2} \mathrm{~F}_{2}$ onto aqueous surfaces of different $\mathrm{pH}$ $(2,12$ and 4.5 for the upper, middle and lowest trace, respectively). Different concentrations of $\mathrm{SO}_{2} \mathrm{~F}_{2}$ and/or mass spectrometer sensitivity is the cause of the vertical displacement of the data from each experiment.

(1974) found significantly lower loss rates of $\mathrm{SO}_{2} \mathrm{~F}_{2}$ in acidified solutions ( $\mathrm{pH}$ as low as 2), suggesting that only loss to alkaline aqueous surfaces is of significance.

\subsection{Atmospheric implications}

In the following section we make some simple calculations on the lifetime of $\mathrm{SO}_{2} \mathrm{~F}_{2}$ with respect to various loss processes in different parts of the atmosphere and, based on this, a qualitative estimate of its global warming potential.

\subsubsection{Reaction with $\mathrm{OH}$ in the troposphere}

We have shown that $\mathrm{SO}_{2} \mathrm{~F}_{2}$ reacts only very slowly with the $\mathrm{OH}$ radical. A lower limit to its tropospheric lifetime with respect to loss by reaction with $\mathrm{OH}$ can be obtained by combining a diurnally and globally averaged $\mathrm{OH}$ concentration of $1 \times 10^{6}$ molecule $\mathrm{cm}^{-3}$ with the rate coefficient of $k_{2} \leq 1 \times 10^{-15} \mathrm{~cm}^{3}$ molecule $\mathrm{e}^{-1} \mathrm{~s}^{-1}$ as presented here. The resultant lifetime exceeds 30 years and is strictly a lower limit for a number of reasons. Firstly, as already mentioned our determination of the rate coefficient $k_{2}$ is an upper limit, as loss of $\mathrm{OH}$ was (probably) driven by reactive impurities in our $\mathrm{SO}_{2} \mathrm{~F}_{2}$ sample. Secondly, the absence of any easily abstractable atoms in $\mathrm{SO}_{2} \mathrm{~F}_{2}$ implies a significant barrier to 
reaction and that the rate coefficient will most likely decrease rapidly with altitude in the troposphere as the temperature decreases. Thus the true lifetime of $\mathrm{SO}_{2} \mathrm{~F}_{2}$ with respect to reaction by $\mathrm{OH}$ could easily be an order of magnitude longer than the lower limit calculated here.

3.6.2 Heterogeneous loss/dry deposition of $\mathrm{SO}_{2} \mathrm{~F}_{2}$ in the boundary layer

The value of $\gamma_{\text {expt }}$ obtained in this study can be used to estimate the lifetime of atmospheric $\mathrm{SO}_{2} \mathrm{~F}_{2}$ with respect to its uptake to aqueous surfaces. For uptake coefficients lower than $\approx 10^{-3}$, the following expression defines the lifetime ( $\tau$, $\mathrm{s})$ in the presence of aerosol of loading $A\left(\mathrm{~cm}^{2} \mathrm{~cm}^{-3}\right)$ :

$$
\tau=\frac{4}{\gamma_{\operatorname{expt}} \cdot \bar{c} \cdot A}
$$

Following Sander and Crutzen (1996) we assume an average surface area density of $A=5 \times 10^{-7} \mathrm{~cm}^{2} / \mathrm{cm}^{3}$ for the marine boundary layer, which results in a lower limit to the $\mathrm{SO}_{2} \mathrm{~F}_{2}$ lifetime of 100 years in this environment. This must however be considered a lower limit to the lifetime with respect to aerosol loss, as atmospheric aerosol is nearly always acidic and, as shown by Cady and Misra (1974) $\mathrm{SO}_{2} \mathrm{~F}_{2}$ does not interact strongly with aqueous neutral or acidic surfaces. Indeed, using expression (11) (and using the coefficients for solubility and hydrolysis of Cady and Misra) and we can calculate a value of $\gamma_{\text {react }} \approx 2 \times 10^{-9}$, which would be representative of uptake to the ocean surface with an average temperature of $20^{\circ} \mathrm{C}$ and $\mathrm{pH}$ of $\left.\approx 8\left([\mathrm{OH}]^{-}=1 \times 10^{-6} \mathrm{~mol} \mathrm{~L}^{-1}\right)\right)$. Note that at $\mathrm{pH}$ values greater than 7.5, hydrolysis is dominated by reaction with $\mathrm{OH}^{-}$and direct reaction with water can be neglected. The value of $\gamma=2 \times 10^{-9}$ can be used to calculate the deposition velocity to the ocean using:

$v_{\mathrm{dep}}=\frac{\gamma \cdot \bar{c}}{4}$

which gives us $v_{\text {dep }}=1.2 \times 10^{-5} \mathrm{~cm} \mathrm{~s}^{-1}$. Combining the deposition velocity with recent measurements of the $\mathrm{SO}_{2} \mathrm{~F}_{2}$ concentration of $\approx 1 \mathrm{ppt}$ (Mühle, 2006) and the ocean surface area of $\approx 3.6 \times 10^{8} \mathrm{~km}^{2}$ allows us to calculate that $\approx 6 \times 10^{3} \mathrm{~kg}$ of $\mathrm{SO}_{2} \mathrm{~F}_{2}$ will annually be lost to the oceans. This number is negligibly small in comparison to the present annual atmospheric release rate, which is clearly larger than $10^{6} \mathrm{~kg} / \mathrm{year}$ (see Introduction).

\subsubsection{Loss of $\mathrm{SO}_{2} \mathrm{~F}_{2}$ in the stratosphere}

We have shown that $\mathrm{SO}_{2} \mathrm{~F}_{2}$ does react efficiently with $\mathrm{O}\left({ }^{1} \mathrm{D}\right)$ atoms, thus opening a potential sink in the stratosphere. A rough guide to its lifetime with respect to reaction with $\mathrm{O}\left({ }^{1} \mathrm{D}\right)$ can be obtained by comparison to $\mathrm{N}_{2} \mathrm{O}$, which has a stratospheric lifetime of about 130 years, mainly $(90 \%)$ a result of photolysis, the remainder due to reaction with $\mathrm{O}\left({ }^{1} \mathrm{D}\right)$. The lifetime of $\mathrm{N}_{2} \mathrm{O}$ with respect to reaction with $\mathrm{O}\left({ }^{1} \mathrm{D}\right)$ can thus be estimated as $>1000$ years. As the rate coefficient $\left(k_{1 b}\right)$ for reaction of $\mathrm{O}\left({ }^{1} \mathrm{D}\right)$ with $\mathrm{SO}_{2} \mathrm{~F}_{2}$ is approximately a factor of two slower than $\mathrm{N}_{2} \mathrm{O}$ with $\mathrm{O}\left({ }^{1} \mathrm{D}\right)$ we can estimate a lifetime in excess of 2000 years with respect to loss by (R1). Although the VUV spectrum of $\mathrm{SO}_{2} \mathrm{~F}_{2}$ was not studied in this work, we can also coarsely evaluate the lifetime of $\mathrm{SO}_{2} \mathrm{~F}_{2}$ with respect to photolysis in the stratosphere by comparison with $\mathrm{N}_{2} \mathrm{O}$. Within the important wavelength region for $\mathrm{N}_{2} \mathrm{O}$ photolysis (185-210 nm), the absorption cross sections of $\mathrm{SO}_{2} \mathrm{~F}_{2}$ (Pradayrol et al., 1996) are consistently a factor of five to ten less than those of $\mathrm{N}_{2} \mathrm{O}$, which would convert to a photolytic lifetime in excess of 500 years. Accurate study of the $\mathrm{SO}_{2} \mathrm{~F}_{2}$ cross sections in the relevant wavelength range, and calculation of the J-value with an appropriate radiation transfer model would be useful to confirm this. Clearly however, $\mathrm{SO}_{2} \mathrm{~F}_{2}$ is too long lived in the lower stratosphere to contribute significantly to the sulphate layer.

\subsection{4 $\mathrm{SO}_{2} \mathrm{~F}_{2}$ as a greenhouse gas?}

In the absence of an important chemical sink process for $\mathrm{SO}_{2} \mathrm{~F}_{2}$ once released into the atmosphere, we must consider its potential role as an atmospheric greenhouse gas. The $\mathrm{SO}_{2} \mathrm{~F}_{2}$ IR absorption features in the $814-918 \mathrm{~cm}^{-1}$ spectral range are located within the "atmospheric window" and, via model calculations of the atmospheric sources, sinks and distribution of $\mathrm{SO}_{2} \mathrm{~F}_{2}$, the integrated band intensity (Table 3) can be used to estimate the greenhouse warming potential (GWP) of this gas. Whilst an in-depth study is beyond the scope of this publication, and would require a more complete set of $\mathrm{SO}_{2} \mathrm{~F}_{2}$ IR spectral measurements, we can compare the integrated band intensity with that of another, long lived fluorinated sulphur species, $\mathrm{SF}_{6}$, which has one of the largest GWPs (over a 100 year period) of all known atmospheric trace gases. The integrated band intensity for the $\mathrm{SF}_{6} \mathrm{ab}-$ sorption feature at $\approx 950 \mathrm{~cm}^{-1}$ is circa 5000 (see Sect. 3.4) a factor of just 3.3 larger than $\mathrm{SO}_{2} \mathrm{~F}_{2}$. We note that the absorption feature of $\mathrm{SO}_{2} \mathrm{~F}_{2}$ at $\approx 7.9 \mu \mathrm{m}$ also absorbs (albeit more weakly) within the atmospheric window. Given the long lifetime of $\mathrm{SO}_{2} \mathrm{~F}_{2}$ and the expected increase in its production rate over the next decades it is plausible that this species could indeed become an important greenhouse gas. This needs to be thoroughly evaluated in detailed modelling studies.

\section{Conclusions}

In a series of laboratory studies we have investigated a number of reactions that could contribute to the chemical removal of $\mathrm{SO}_{2} \mathrm{~F}_{2}$ from the atmosphere. Experimental data was obtained for reaction of $\mathrm{SO}_{2} \mathrm{~F}_{2}$ with excited oxygen atoms $\left(\mathrm{O}\left({ }^{1} \mathrm{D}\right)\right)$, the $\mathrm{OH}$ radical, $\mathrm{O}_{3}$ and with aqueous surfaces. The reaction with $\mathrm{O}\left({ }^{1} \mathrm{D}\right)$ proceeds both by energy transfer (quenching of $\mathrm{O}\left({ }^{1} \mathrm{D}\right), \approx 55 \%$ ) and product formation $(\approx 45 \%)$, with an overall rate coefficient of 
$k_{1}(220-300 \mathrm{~K})=(1.3 \pm 0.2) \times 10^{-10} \mathrm{~cm}^{3}$ molecule ${ }^{-1} \mathrm{~s}^{-1}$. Upper limits for the rate coefficients $\left(\mathrm{cm}^{3}\right.$ molecule $\left.{ }^{-1} \mathrm{~s}^{-1}\right)$ for reaction of $\mathrm{SO}_{2} \mathrm{~F}_{2}$ with $\mathrm{OH}\left(k_{2}<1 \times 10^{-15}\right)$ and $\mathrm{O}_{3}$ $\left(k_{3}<1 \times 10^{-23}\right)$ were obtained. No evidence for loss to aqueous surfaces was obtained. The kinetic data allowed us to estimate very long chemical lifetimes for $\mathrm{SO}_{2} \mathrm{~F}_{2}$ in all parts of the lower atmosphere, which, together with our measurements of infra-red absorption bands in the atmospheric window, suggest that $\mathrm{SO}_{2} \mathrm{~F}_{2}$ may have a large greenhouse warming potential.

Acknowledgements. T. J. Dillon acknowledges the support of the Max Planck Society in the provision of a research grant. We are indebted to P. Crutzen for providing motivation and for helpful discussions.

Edited by: V. F. McNeill

\section{References}

Atkinson, R., Baulch, D. L., Cox, R. A., Crowley, J. N., Hampson, R. F., Hynes, R. G., Jenkin, M. E., Kerr, J. A., Rossi, M. J., and Troe, J.: IUPAC Subcommittee for gas kinetic data evaluation, evaluated kinetic data: http://www.iupac-kinetic.ch.cam.ac.uk/, 2007.

Blitz, M. A., Dillon, T. J., Heard, D. E., Pilling, M. J., and Trought, I. D.: Laser induced fluorescence studies of the reactions of $\mathrm{O}\left({ }^{1} \mathrm{D}_{2}\right)$ with $\mathrm{N}_{2}, \mathrm{O}_{2}, \mathrm{~N}_{2} \mathrm{O}, \mathrm{CH}_{4}, \mathrm{H}_{2}, \mathrm{CO}_{2}, \mathrm{Ar}, \mathrm{Kr}$ and $n-\mathrm{C}_{4} \mathrm{H}_{10}$, Phys. Chem. Chem. Phys., 6, 2162-2171, 2004.

Cady, G. H. and Misra, S.: Hydrolysis of sulfuryl fluoride, Inorg. Chem., 13, 837-841, 1974.

Carl, S. A.: A highly sensitive method for time-resolved detection of $\mathrm{O}\left({ }^{1} \mathrm{D}\right)$ applied to precise determination of absolute $\mathrm{O}\left({ }^{1} \mathrm{D}\right)$ reaction rate constants and $\mathrm{O}\left({ }^{3} \mathrm{P}\right)$ yields, Phys. Chem. Chem. Phys., 7, 4051-4053, 2005.

Crutzen, P. J.: The possible importance of CSO for the sulfate layer of the stratosphere, Geophys. Res. Lett., 3, 73-76, 1976.

Dillon, T. J., Horowitz, A., and Crowley, J. N.: Absolute rate coefficients for the reactions of $\mathrm{O}\left({ }^{1} \mathrm{D}\right)$ with a series of n-alkanes, Chem. Phys. Lett., 14, 12-16, 2007.

Dillon, T. J., Karunanandan, R., and Crowley, J. N.: The reaction of $\mathrm{IO}$ with $\mathrm{CH}_{3} \mathrm{SCH}_{3}$ : products and temperature dependent rate coefficients by laser induced fluorescence, Phys. Chem. Chem. Phys., 8, 847-855, 2006.

Dunlea, E. J. and Ravishankara, A. R.: Kinetic studies of the reactions of $\mathrm{O}\left({ }^{1} \mathrm{D}\right)$ with several atmospheric molecules, Phys. Chem. Chem. Phys., 6, 2152-2161, 2004a.

Dunlea, E. J. and Ravishankara, A. R.: Measurement of the rate coefficient for the reaction of $\mathrm{O}\left({ }^{1} \mathrm{D}\right)$ with $\mathrm{H}_{2} \mathrm{O}$ and re-evaluation of the atmospheric $\mathrm{OH}$ production rate, Phys. Chem. Chem. Phys., 6, 3333-3340, 2004b.

Dunlea, E. J., Ravishankara, A. R., Strekowski, R. S., Nicovich, J. M., and Wine, P. H.: Temperature-dependent quantum yields for $\mathrm{O}\left({ }^{3} \mathrm{P}\right)$ and $\mathrm{O}\left({ }^{1} \mathrm{D}\right)$ production from photolysis of $\mathrm{O}_{3}$ at $248 \mathrm{~nm}$, Phys. Chem. Chem. Phys., 6, 5484-5489, 2004.

European Union: Competent Authority Report, Document III-B7, 2005

Fickert, S., Adams, J. W., and Crowley, J. N.: Activation of $\mathrm{Br}_{2}$ and $\mathrm{BrCl}$ via uptake of $\mathrm{HOBr}$ onto aqueous salt solutions, J. Geophys. Res., 104, 23 719-23 727, 1999.
Fickert, S., Helleis, F., Adams, J. W., Moortgat, G. K., and Crowley, J. N.: Reactive uptake of $\mathrm{ClNO}_{2}$ on aqueous bromide solutions, J. Phys. Chem., 102, 10 689-10 696, 1998.

Karunanandan, R., Hölscher, D., Dillon, T. J., Horowitz, A., and Crowley, J.: Reaction of $\mathrm{HO}$ with glycolaldehyde, $\mathrm{HOCH}_{2} \mathrm{CHO}$ : Rate coefficients (240-362 K) and mechanism, J. Phys. Chem. A, 111, 897-908, 2007.

Ko, M. K. W., Sze, N. D., Wang, W. C., Shia, G., Goldman, A., Murcray, F. J., Murcray, D. G., and Rinsland, C. P.: Atmospheric Sulfur-Hexafluoride - Sources, Sinks and Greenhouse Warming, J. Geophys. Res., 98, 10 499-10 507, 1993.

Kollman, W. S.: Sulfuryl fluoride (Vikane) Risk Characterisation Document Volume III. Environmental Fate, Environmental Monitoring Branch, Department of Pesticide Regulation, California Environmental Protection Agency, Sacramento, CA, 2006.

Mühle, J., Harth, C. M., Salameh, P. K., Miller, B. R., Porter, L. W., Fraser, P. J., Greally, B. R., O’Doherty, S., and Weiss, R. F.: Global Measurements of Atmospheric Sulfuryl Fluoride $\left(\mathrm{SO}_{2} \mathrm{~F}_{2}\right)$, Eos Trans. AGU, 87(52), Fall Meet. Suppl., Abstract A53B-0191, 2006.

NIST Chemistry WebBook: NIST Standard Reference Database Number 69, http://webbook.nist.gov/chemistry/, edited by: Linstrom, P. J. and Mallard, W. G., 2005.

Pradayrol, C., Casanovas, A. M., Deharo, I., Guelfucci, J. P., and Casanovas, J.: Absorption coefficients of $\mathrm{SF}_{6}, \mathrm{SF}_{4}, \mathrm{SOF}_{2}$ and $\mathrm{SO}_{2} \mathrm{~F}_{2}$ in the vacuum ultraviolet, J. Phys. III, 6, 603-612, 1996.

Raber, W. H. and Moortgat, G. K.: Photooxidation of selected carbonyl compounds in air, in: Problems and Progress in Atmospheric Chemistry, edited by: Barker, J. R., World Scientific Publishing Co. Pte. Ltd, Singapore, 318-373, 2000.

Sander, R. and Crutzen, P. J.: Model study indicating halogen activation and ozone destruction in polluted air masses transported to the sea, J. Geophys. Res., 101, 9121-9138, 1996.

Sander, S. P., Friedl, R. R., Golden, D. M., Kurylo, M. J., Huie, R. E., Orkin, V. L., Moortgat, G. K., Ravishankara, A. R., Kolb, C. E., Molina, M. J., and Finlayson-Pitts, B. J.: Chemical kinetics and photochemical data for use in atmospheric studies: Evaluation Number 15, Jet Propulsion Laboratory, National Aeronautics and Space Administration/Jet Propulsion Laboratory/California Institute of Technology, Pasadena, CA, 2006.

Schofield, K.: Rate constants for gaseous interactions of $\mathrm{O}\left({ }^{1} \mathrm{D}_{2}\right)$ and $\mathrm{O}\left({ }^{1} \mathrm{~S}_{0}\right)-$ Critical evaluation, J. Photochem., 9, 55-68, 1978

Seinfeld, J. H.: Atmospheric chemistry and physics of air pollution, John Wiley and Sons, 1986.

Strekowski, R. S., Nicovich, J. M., and Wine, P. H.: Temperaturedependent kinetics study of the reactions of $\mathrm{O}\left({ }^{1} \mathrm{D}_{2}\right)$ with $\mathrm{N}_{2}$ and $\mathrm{O}_{2}$, Phys. Chem. Chem. Phys., 6, 2145-2151, 2004.

Takahashi, K., Takeuchi, Y., and Matsumi, Y.: Rate constants of the $\mathrm{O}\left({ }^{1} \mathrm{D}\right)$ reactions with $\mathrm{N}_{2}, \mathrm{O}_{2}, \mathrm{~N}_{2} \mathrm{O}$, and $\mathrm{H}_{2} \mathrm{O}$ at $295 \mathrm{~K}$, Chem. Phys. Lett., 410, 196-200, 2005.

Teruel, M. A., Dillon, T. J., Horowitz, A., and Crowley, J. N.: Reaction of $\mathrm{O}\left({ }^{3} \mathrm{P}\right)$ with the alkyl iodides: $\mathrm{CF}_{3} \mathrm{I}, \mathrm{CH}_{3} \mathrm{I}, \mathrm{CH}_{2} \mathrm{I}_{2}, \mathrm{C}_{2} \mathrm{H}_{5} \mathrm{I}$ $1-\mathrm{C}_{3} \mathrm{H}_{7} \mathrm{I}$ and 2- $\mathrm{C}_{3} \mathrm{H}_{7} \mathrm{I}$, Phys. Chem. Chem. Phys., 6, 2172-2178, 2004.

Wollenhaupt, M., Carl, S. A., Horowitz, A., and Crowley, J. N.: Rate coefficients for reaction of $\mathrm{OH}$ with acetone between 202 and 395 K, J. Phys. Chem. A, 104, 2695-2705, 2000. 